University of South Florida

DIGITAL COMMONS

@ UNIVERSITY OF SOUTH FLORIDA
Digital Commons @ University of

South Florida

3-1-2006

\title{
Special Event Transportation Service Planning \& Operations Strategies for Transit
}

CUTR

Follow this and additional works at: https://digitalcommons.usf.edu/cutr_nctr

\section{Recommended Citation}

"Special Event Transportation Service Planning \& Operations Strategies for Transit," National Center for Transit Research (NCTR) Report No. CUTR-NCTR-RR-2004-13, Center for Urban Transportation Research, University of South Florida, 2006.

DOI: https://doi.org/10.5038/CUTR-NCTR-RR-2004-13

Available at: https://scholarcommons.usf.edu/cutr_nctr/180

This Technical Report is brought to you for free and open access by the National Center for Transit Research (NCTR) Archive (2000-2020) at Digital Commons @ University of South Florida. It has been accepted for inclusion in Research Reports by an authorized administrator of Digital Commons @ University of South Florida. For more information, please contact digitalcommons@usf.edu. 


\title{
Special Event Transportation Service Planning and Operations Strategies for Transit
}

\author{
Project \#BD549-09
}

\section{FINAL REPORT}

\author{
Prepared for the \\ Florida Department of Transportation \\ Research Center
}

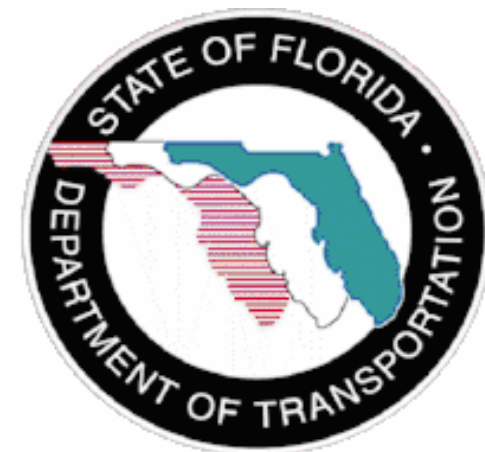

Prepared by the

National Center for Transit Research (NCTR)

Center for Urban Transportation Research

University of South Florida

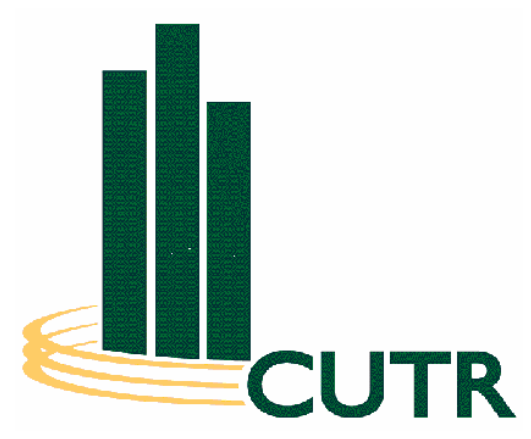

March 2006 


\section{Disclaimer}

The opinions, findings, and conclusions expressed in this publication are those of the authors and not necessarily those of the Florida Department of Transportation. 


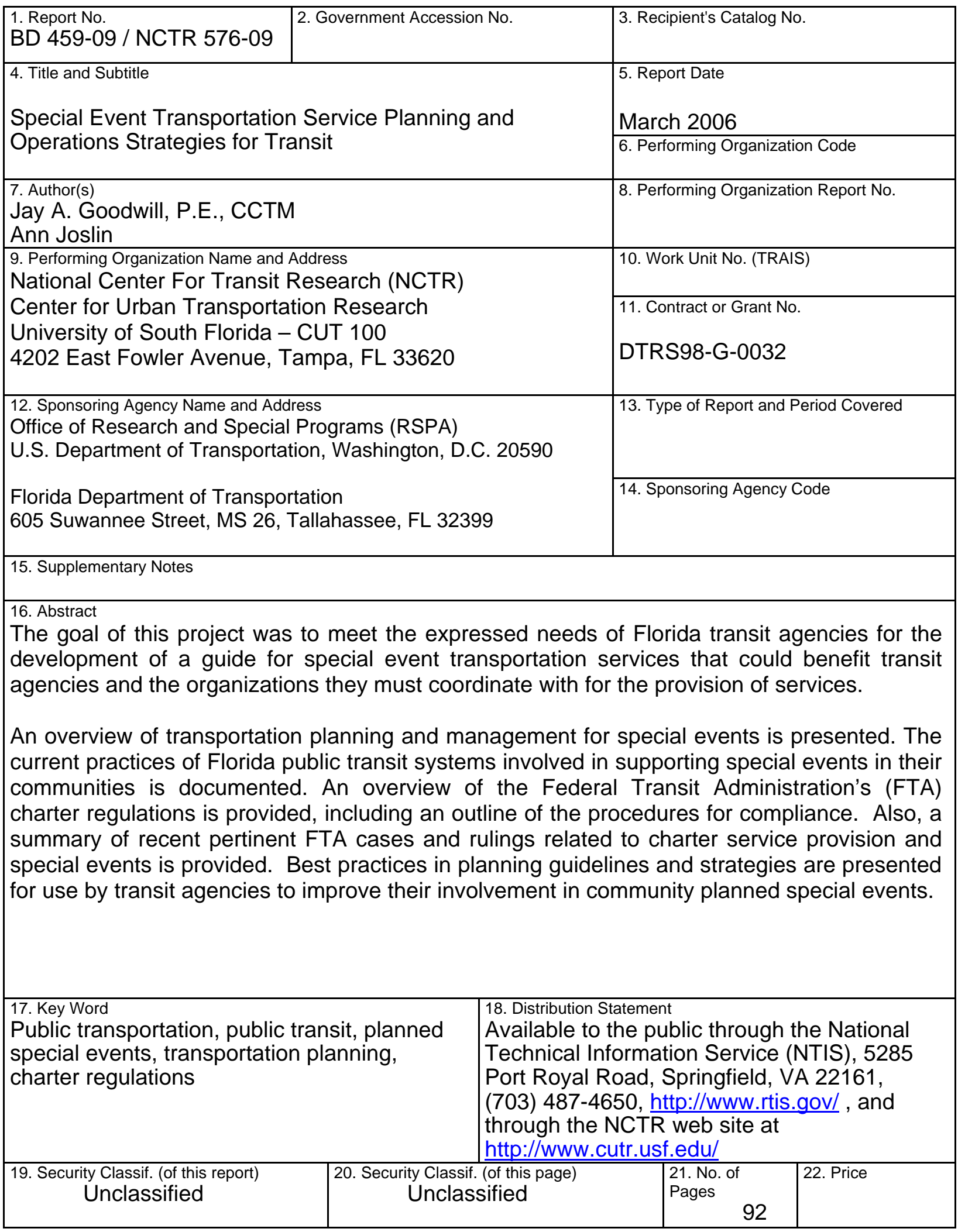




\section{Table of Contents}

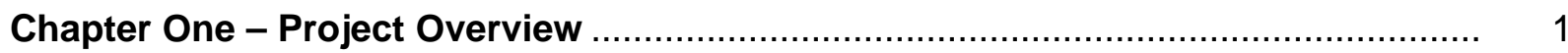

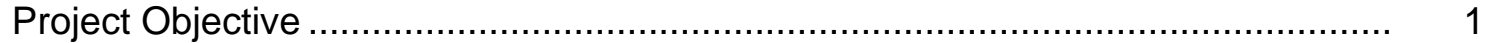

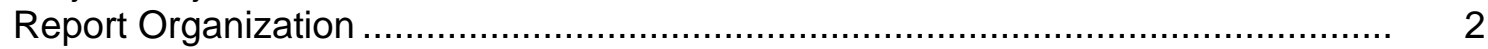

Chapter Two - Transportation Planning and Management for Special Events .......... 3

Introduction.................................................................................... 3

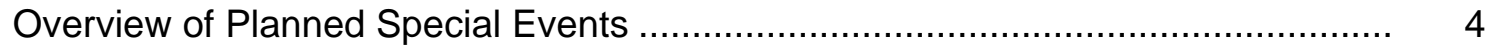

Chapter Three - Current Practices of Florida Transit Agencies .............................. 10

Survey Instrument and Methodology ........................................................... 10

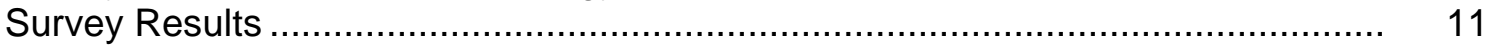

Policies and Procedures......................................................................... 12

Conclusions and Observations.................................................................... 15

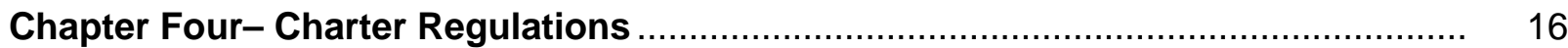

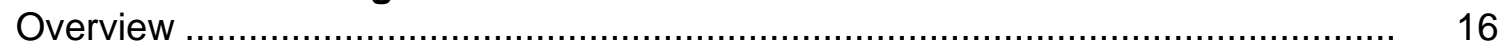

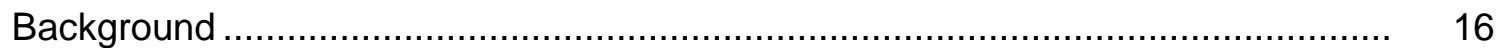

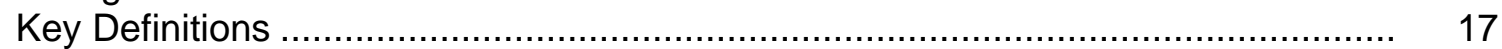

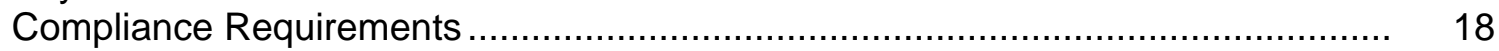

Evaluation of Compliance....................................................................... 22

Summary of Recent FTA Charter Determinations............................................... 24

Chapter Five - Best Practices and Guidelines ……………................................. 28

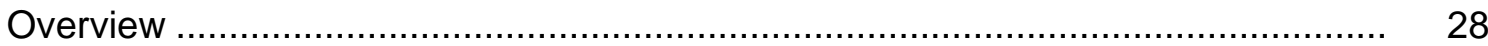

Research Methodology …................................................................... 28

Guidelines and Best Practices ................................................................. 29

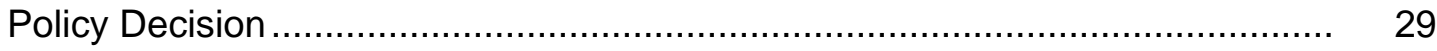

Planning and Procedures ........................................................................ 31

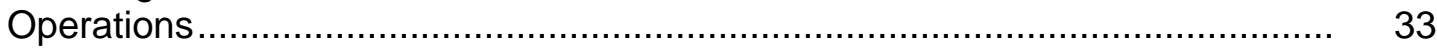

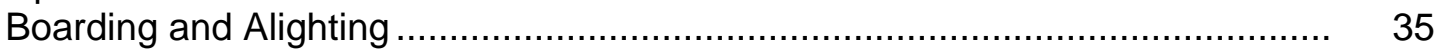

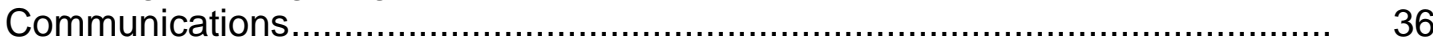

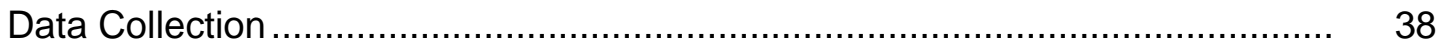

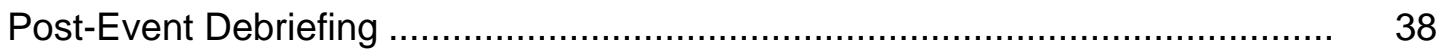

References

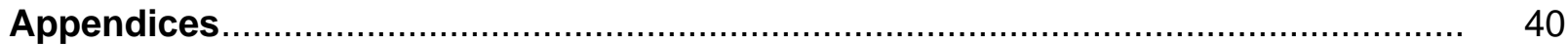

Appendix A: Survey Instrument............................................................... 41

Appendix B: Louisville Metro Special Event Permit Application ............................. 43

Appendix C: Sample Service Plan ................................................................ 49

C-1: JTA Jacksonville Super Bowl XXXIX .............................................. $\quad 50$

C-2: VOTRAN Pepsi 400 Winston Cup Series Race ………………………... 55

C-3: LYNX Florida Classic ..................................................................... 66

C-4: Chicago Transit Authority (CTA) Taste of Chicago …………………....... 77 


\section{Chapter One}

\section{Project Overview}

\section{Project Objective}

The goal of this project was to meet the expressed needs of Florida transit agencies for the development of a guide for special event transportation services that could benefit transit agencies and the organizations with whom they must coordinate for the provision of services. Unlike regular transit service planning, service for special events presents a challenge for service providers in that they are non-recurring events without a predictable transit demand, transit agencies must work cooperatively with other stakeholders, and supplemental service is provided in addition to normal transit services. Special events services are one of the biggest attractors of non-regular riders, presenting a unique opportunity to market the transit agency's services to the community.

Unfortunately, service for special events is often subject to ad hoc planning and designed based on tradition rather than with a systematic approach to meet the transit agency's goals. Often, the inherent benefits of providing special events services are never realized by the transit agency, and costs are not minimized.

Special events range from very large events such as the Olympics to very small events such as a local community parade; this report includes information and best practices that will be useful in the provision of any type of special event service. This service guide includes strategies for coordination within and among relevant agencies, key considerations before undertaking special event transportation services, and a framework to enable service providers to proactively plan and successfully deliver these services.

The delivery of transportation services during special events often requires the cooperation of agencies that do not usually work together. However, cooperative planning during periods of increased travel demand offers a unique opportunity to pursue innovative operational practices and apply technologies to improve the performance of the overall transportation system through more effective utilization of available roadway and service capacity 
Given the existing and growing potential for special events in various urban areas of Florida and the growing need for transit agencies to attract new riders, it is vital that transit agencies utilize an operations reference resource to ensure effective planning and efficient service delivery.

\section{$\underline{\text { Report Organization }}$}

Chapter Two presents an overview of transportation planning and management for special events. Recent research efforts are discussed, including public agency efforts to raise the awareness of the importance of continuously improving how travel is managed for planned special events and the important role coordinated planning plays in mobility and travel reliability across various transportation modes. This chapter also details the potential benefits of public transit agency involvement in the process.

Chapter Three summarizes the efforts to determine the extent to which Florida public transit systems are involved in supporting special events in their communities. The objective is to ascertain the amount and types of special event services provided, the level of coordination with other stakeholders, and the degree to which written policies and procedures are used.

The ability and willingness of public transit agencies to participate in special event transportation services are greatly influenced by the Federal Transit Administration's (FTA) charter regulations. Chapter Four provides an overview of FTA charter regulations, outlines procedures for compliance, and provides a summary of recent pertinent FTA cases and rulings related to charter service provision and special events.

Chapter Five provides a summary of current practices related to the provision of special event transportation services. The findings of this chapter are based on field observations, discussions, and interviews with agency staff involved in special event services and a review of existing literature on this subject. Best practices in planning guidelines and strategies are presented for use by transit agencies to enhance their involvement in their community's planned special events. 


\section{Chapter Two}

\section{Transportation Planning and Management for Special Events}

\section{$\underline{\text { Introduction }}$}

The transportation industry recently focused its attention on the activities related to a comprehensive approach to the planning and management of special events. Based on the 1988 National Highway Institute's definition, a special event is an occurrence that "abnormally increases traffic demand." Special events include sporting events, parades, fairs, and other planned events. Two recent publications and a first-time national conference summarized below put the spotlight on a more comprehensive approach to the transportation aspects of planning and management of special events.

The National Cooperative Highway Research Program (NCHRP) Synthesis 309 provided a synopsis of highway practices for "Transportation Planning and Management for Special Events." ${ }^{1}$ This effort was one of the first to focus on the state-of-the-practice for transportation planning and management of special events. The report noted the lack of special event related literature. When identifying key stakeholders in the special event planning process, public transit was identified only as a secondary stakeholder. Transit's potential role in assisting in the special event planning and management process has since become more evident.

The most comprehensive document on special event transportation found in this research was the Federal Highway Administration's (FHWA) report entitled "Managing Travel for Planned Special Events Handbook" in September 2003. ${ }^{2}$

As noted, the primary focus of these reports was the impacts that planned special events have on the highway network. This document attempts to complement NCHRP and FHWA reports by offering a specific focus on public transportation agency involvement and participation in planned special events.

Another key event that focused on the comprehensive approach was the first National Conference on Managing Travel for Planned Special Events held in New Orleans from 
December 1-3, 2004. The conference was organized to raise public agency awareness of the importance and need to continuously improve how travel is managed for planned special events, which can significantly impact mobility and travel reliability across all surface transportation modes.

The remainder of this chapter provides an overview of planned special events, the role of transportation planning and management of special events, and a context for public transit agency involvement in the process.

The following section utilizes materials from the above documents, as well as the Federal Highway Administration Office of Operation's website, ${ }^{3}$ including the two documents entitled "Fact Sheet" and "Frequently Asked Questions."

\section{Overview of Planned Special Events}

\section{What is a planned special event?}

A planned special event is a public activity with a scheduled time, location and duration that may impact the normal operation of the surface transportation system due to increased travel demand and/or reduced capacity attributed to event staging.

Planned special events include sporting events, concerts, festivals, and conventions occurring at permanent multi-use venues (e.g., arenas, stadiums, racetracks, fairgrounds, amphitheaters, convention centers). They also include less frequent public events such as parades, fireworks displays, bicycle races, sporting games, motorcycle rallies, seasonal festivals, and milestone celebrations at temporary venues.

The term planned special event is used to describe these activities because of their known locations, scheduled times of occurrence, and associated operating characteristics. Emergencies, such as a severe weather event or other major catastrophe, represent special events that can induce extreme traffic demand under an evacuation condition. However, these events occur at random and with little or no advance warning, unlike the characteristics of planned special events. 


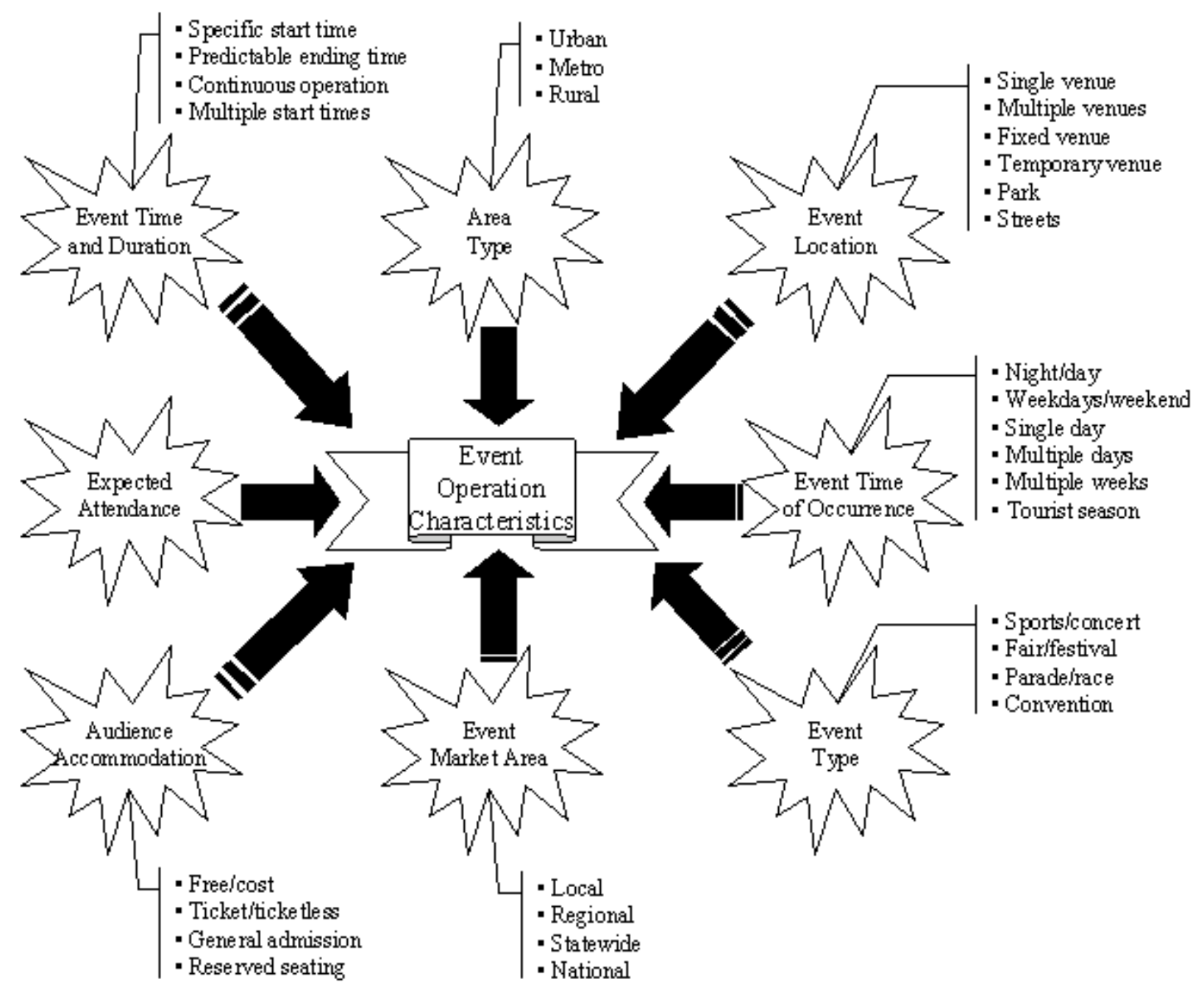

Are there different categories of planned special events?

The operational characteristics of planned special events create the following five event categories:

- Discrete/recurring event at a permanent venue (e.g., sporting and concert events), characterized by specific starting and predictable ending times, known venue capacity, advance ticket sales, and weekday event occurrences.

- Continuous event (e.g., fairs and festivals), characterized by occurrence often over multiple days, arrival and departure of event patrons throughout the event day, typically 
little or no advance ticket sales, capacity of venue not always known, and occurrence sometimes at temporary venues.

- $\quad$ Street use event (e.g., parades and street races), characterized by occurrence on a roadway requiring temporary closure, specific starting and predictable ending times, capacity of spectator viewing area not known, spectators not charged or ticketed, and dedicated parking facilities not available.

- Regional/multi-venue event, characterized by the occurrence of events at multiple venues and at or near the same time.

- Rural event, characterized by rural or rural/tourist area, high attendance events attracting event patrons from a regional area, limited roadway capacity serving an event venue, area lacking regular transit service, and events having either a time specific duration or continuous duration.

Who are the stakeholders that may be involved with managing travel for planned special events?

Traffic operations agencies, transit agencies, law enforcement agencies, and event organizers represent key stakeholders in the transportation management plan development process because of the responsibility they bear in developing, approving, and implementing the plan. To ensure that the plan addresses the requirements of all those impacted, the event planning team should be comprised of a wide range of stakeholders:

- Event operations stakeholders focus on mitigating the safety, mobility, and reliability impacts on transportation operations.

- Community interest stakeholders seek to minimize impacts on community quality of life and maximize potential social and economic benefits.

- Event support stakeholders serve to support and execute the transportation management plan by following proposed initiatives or providing necessary resources for plan deployment. 


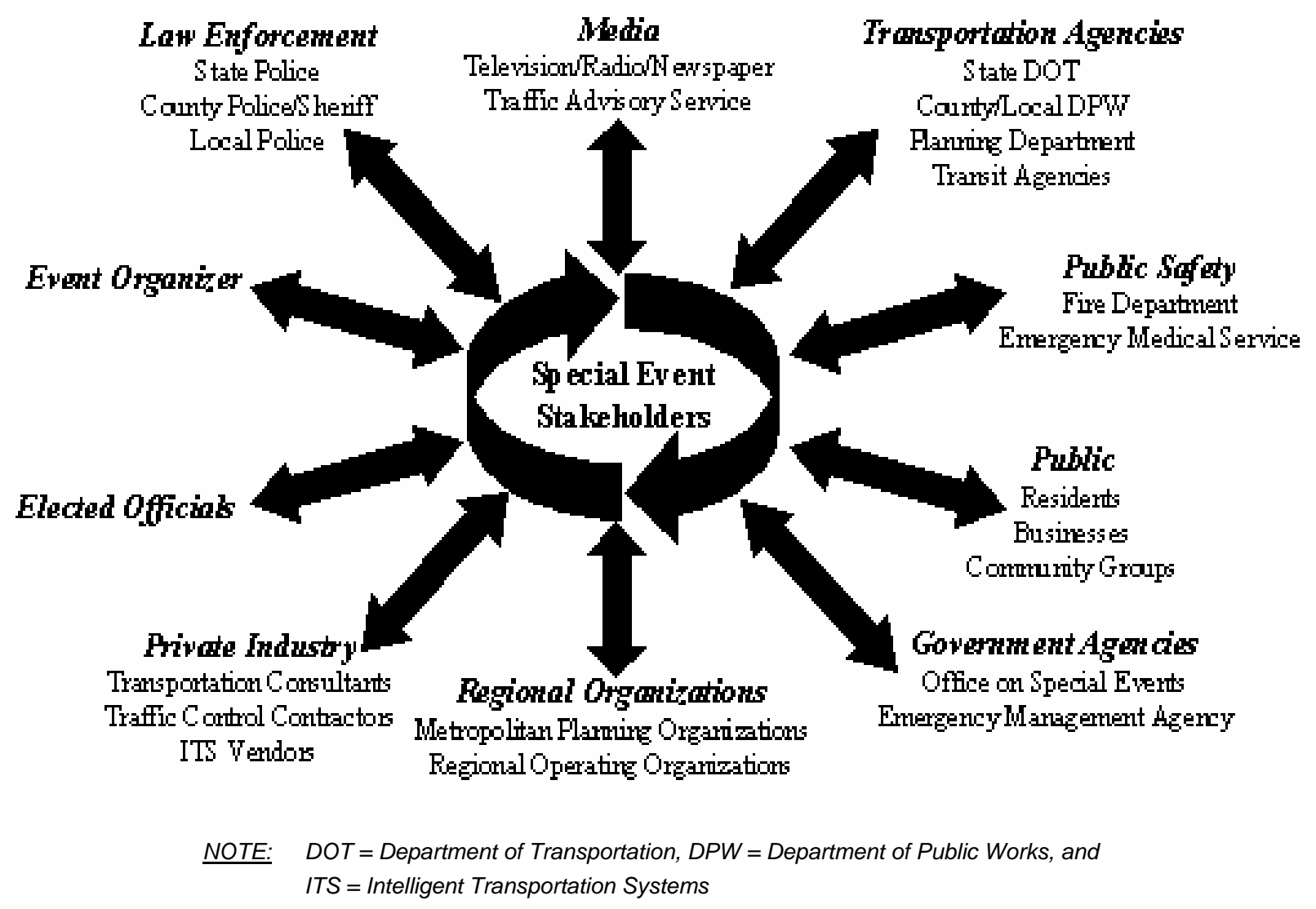

How do transit agencies support a traffic management team?

Modifications to existing transit service for a planned special event serve to reduce traffic demand on the roadway network serving the event venue. The goal of a public transit agency is to increase ridership during the event by increasing the attractiveness of the service that it provides. In many locations and for many types of planned special events, additional ridership to and from special event sites can provide substantial additional revenue for the transit agency at little additional cost. Also, transit system use may relieve or minimize traffic congestion around the venue.

Transit agencies may develop a specialized transit plan detailing schedules and necessary equipment and personnel resources. The transit plan may specify one or more categories of transit operation on the day-of-event that include: 
- Existing service plus additional vehicle hours (e.g., more frequent service or expanded hours of operation)

- Existing service plus route deviation (e.g., includes new stop at transit station(s) near venue)

- Express service (e.g., new route and schedule)

- Charter service (e.g., contract service)

What are the overall benefits of managing travel for special events?

Among the numerous benefits of managing travel at special events are:

- Reduced delay for motorists attending the planned special event through more active information dissemination, traffic management, and alternate mode use

- Reduced delay for motorists not attending the special event through active promotion of alternate routes or modes

- Reduced overall traffic demand at or near the special event site through active promotion of alternate routes or modes or dissemination of information, resulting in the cancellation or delay of unnecessary trips

- Improved safety through more active traffic management and reduced motorist frustration

- Maintaining the attractiveness of the special event venue to encourage people to return in the future

What are the stakeholder's benefits of managing travel for planned special events?

The proactive management of travel for planned special events yields numerous benefits to stakeholders and transportation system operations, including:

- Reducing traffic congestion

- Improving mobility

- Improving travel safety

- Facilitating partnerships and building trust

- Improving new interagency relationships crossing jurisdictional boundaries

- Promoting interagency coordination, resource utilization and sharing 
- Incorporating new procedures and practices into day-to-day operation of agencies

- Promoting stakeholder efforts in the media

What are the transit agency benefits of managing travel for planned special events?

By participating in the planning and management of planned special events, transit agencies realize numerous additional benefits, including:

- Reducing delays for transit system, event attendees and the general public

- Improving safety

- Enhancing interagency cooperation \& relationships with stakeholders

- Developing community recognition of the value of transit

- Attracting potential new riders

- Exposing transit system to non-riders 


\section{Chapter Three \\ Current Practices of Florida Transit Agencies}

One of the first steps in this research effort was to determine the extent that Florida public transit systems were involved in supporting special events in their communities. The objectives were to ascertain the number and types of special events served with transit, reveal the degree of coordination with other stakeholders, and determine if written policies and procedures were utilized. This chapter summarizes the efforts and key findings.

\section{Survey Instrument and Methodology}

A simple one-page survey instrument was developed and distributed via e-mail to the General Managers and Executive Directors of the 28 public transit systems that operate fixed-route service within Florida. In addition to the original e-mail request to the transit agencies, two additional follow up requests were made to seek agency participation.

The survey instrument (included in Appendix A) consisted of five basic sections with questions used to determine:

- If the agency provides any transportation services for special events?

- If they do not provide special events services, why?

- If the agency provides transportation for special events, what are the characteristics of those services?

- Event name

○ Duration of event

- Frequency of event

- Number of passengers transported

- Degree of coordination with other local agencies

- Description of services

- Written policies and procedures

- Agency contact for special event transportation services 


\section{Survey Results}

Responses were received from 13 agencies, representing a 46.4 percent participation rate, which was somewhat lower than expected. Among the 15 transit agencies that did not respond, five were smaller agencies whose primary focus is the provision of paratransit services. Reluctance to respond to the survey could be related to agency concerns regarding the complexity of maintaining compliance with FTA charter regulations described in Chapter Four.

The survey results showed:

- Of the responding agencies nine of thirteen (69.2\%) stated that they did provide transportation services for special events.

- The FTA charter regulations and lack of adequate resources (vehicles, operators and budget) were cited as the reasons agencies did not provide special event transportation services.

- Among the nine transit agencies providing transportation services for special events, eight $(88.9 \%)$ indicated that their agency participated in pre-event and post-event coordination meetings with other local agencies such as law enforcement, traffic engineering, event planners, etc.

- Further analysis revealed that coordination with other local agencies was usually limited to only the larger events.

- Only five of the nine agencies providing special event transportation (55.6\%) indicated they used written policies and procedures for dealing with special event transportation.

- The responding agencies provided services for the following types of events:

- Large one time events - such as the National Football League (NFL) Super Bowls

○ Recurring sporting events - primarily NFL games and major college football events with parking limitations

- Community events and festivals - such as the Marion County Equine Show or Tri-Rail's participation with the Air and Sea Show

- Holiday season tours - such as Volusia County Transit's (VOTRAN's) holiday light tours 
- Fireworks displays - such as the park-and-ride shuttles provided for Independence Day fireworks displays

- Community parades - such as Hillsborough Area Regional Transit Authority's (HARTline's) Gasparilla Pirate Festival Parade

- While several transit agencies indicated that they provided some of the special event transportation utilizing normal services or supplemental service (additional vehicles on existing routes or extended hours of operation), most required the use of resources (vehicles, operators, and support personnel) beyond those provided in normal services.

\section{$\underline{\text { Policies and Procedures }}$}

Included in the survey responses were examples of the policies and procedures that the Florida transit agencies used to determine if the requested special event transportation requests met established agency criteria, as well as procedural steps to assure that all necessary approvals, sign-offs and preparatory steps were conducted.

One example, included for illustrative purposes, is the process used by HARTline's Special Event Department, as detailed below. ${ }^{6}$

Special Service Definition: Special event transit service focuses on intermittent services operated for seven consecutive days or less and is intended to serve special events. This includes both regular fares or sponsored paid services that meet a special need, do not necessarily follow a regularly scheduled route, and is open to the public.

Request Evaluation Criteria: All requests for special event transportation will be considered and evaluated based upon the following criteria:

- Serving the Public Interest: Community events require the movement of large groups of people during certain hours of the day. These are events that would otherwise seriously restrict traffic movement unless public transit played an expanded role. Historically, these events have been annual events though one-time only events of sufficient size will be considered as well. The 
decision to provide the service will be based on an evaluation of available resources and the need for the service.

- $\quad$ Cost Effectiveness: The special service requested must be evaluated based on both operations and system cost, and on the availability of operators and equipment.

- Patronage Potential: The special service must be evaluated on expected patronage of the service. Past and/or potential ridership will be used to help determine the recommendation for special events service.

- Service Provided By Others: Service that could be operated by other transportation providers such as private charter providers will be governed by FTA regulations 49 Code of Federal Regulations (CFR) Part 604, "Charter Services." Other considerations will include cost and geographic limitations.

- $\quad$ Partnership Building: Special services contribute to the goal of partnership building in the community and enhance the agency role as a community partner and as a facilitator of mobility.

Processing Steps: Recognizing that special event transportation requires significant planning, requests for such services must be submitted well in advance of the event; normally three months is used as a minimum.

The following summarizes the steps that then must be completed by the Special Services Department from the initial request to the completion of the special event transit services:

1. Customer submits request for special services.

2. Agency staff reviews the criteria with Customer and confirms date availability.

3. Agency staff confirms with Operations that resources are available to support the event.

4. Agency contacts Customer with approval/disapproval. If approved, a Special Event Agreement form is provided to the Customer. Customer must complete form and provide the following information:

a. Traffic and crowd control plans (if needed) including contact with appropriate law enforcement 
b. Route planning, including any planned construction

c. Event signage plans

d. Written confirmation of and approval to use parking lots and other key areas related to the special event transportation

e. Designation of pick up and drop off locations at the parking lots and event site

5. Customer completes, executes and submits form with requested information

6. Application is reviewed by the Agency, costs confirmed, and if all is in order signs form for Agency and returns to Customer

7. Vehicle request is input in Special Events database and email confirmation sent to Dispatch

8. Marketing representative (if necessary) is requested to be assigned

9. Once route finalized by Customer and submitted to Agency, Operations drives route, determines frequency and vehicle accessibility needs

10. Agency communicates with Customer and Sponsor and coordinates planning with Operations

11. Agency Customer Service Department is provided event specifics

12. Agency Management Information Systems (MIS) Department is requested to communicate event specifics on Agency website

13. Signage, if required, is created and installed by the Customer. Agency may elect to provide additional signage and must coordinate

14. Agency sends Dispatch a reminder one week prior to the event

15. Dispatch records event ridership numbers into Special Event database after the event

16. Customer submits payment to Agency prior to the event and payment information is entered into database

17. Agency documents special event transportation after the event and a final report is prepared 


\section{$\underline{\text { Conclusions and Observations }}$}

Based upon the findings of the survey of Florida public transit systems, several observations were made:

- Of the responding agencies nine of thirteen (69.2\%) indicated that they did provide some special event transit services.

- The balance of that group, four of thirteen (30.2\%) indicated that they did not provide any special event transportation. While some indicated that limited resources were the reason for this decision, the prevailing factor was the perceived burden placed on the agencies by the FTA charter regulations.

- Of the responding agencies that provide some special event transit service, four of nine (44.4\%) did not have any written procedures and policies for dealing with special event transit services. Appendix C provides some examples of written procedures, policies and operating plans used for special event transportation service provision.

- The coordination between Florida transit agencies and other local agencies appears to be limited and directly correlated to the size and scope of the special events. On one end of the scale are NFL Super Bowls, in which the transit agency is an active participant in the year-long planning efforts. On the other end of the scale are smaller parking lot shuttles that are handled with little coordination with other agencies. 


\section{Chapter Four}

\section{Charter Regulations}

\section{$\underline{\text { Overview }}$}

Due to the unique characteristics of the transportation services required to support each special event, public transportation agencies should carefully review the Federal Transit Administration's (FTA's) charter regulations contained in 49 CFR Section 609.4 to determine the feasibility of providing requested or initiated transportation services. As previously mentioned in Chapter Three, some transit agencies have made a conscious decision not to provide transportation for special events to avoid any potential conflicts with these regulations. On the other hand, many agencies have effectively worked within the parameters of the FTA charter regulations to successfully provide a variety of special event transit services.

This chapter provides the history and intent of FTA's charter regulations, key definitions included in the regulations, required procedures and evaluation of compliance, an overview of exceptions to the regulations, and a summary of FTA findings and determinations for special event transportation services.

\section{Background}

The Federal Transit Administration first addressed private sector participation in the provision of public transportation in the agency's original authorizing legislation, the Urban Mass Transportation Act (UMTA) of 1964 (Public Law 88-365) referred to in this document as "the Act." This statute required recipients of federal transit funding to consider and to use the private sector to the maximum extent possible. The objectives of the legislation were focused on the inclusion of the private sector in participation in local transit programs, ensuring that adequate compensation is provided to a private provider when its transit facilities and equipment are acquired by a state or local government authority and protecting private providers of transit from competition with federally assisted transit providers.

Federal law recognizes the special concerns of private transportation providers that compete with public mass transit authorities. By law, existing private transportation providers are afforded 
certain safeguards from competition. Specifically, FTA is prohibited from providing Federal assistance to a governmental body that provides service in competition with, or supplementary to, service currently provided by a private transportation company. In some cases, the FTA will provide financial assistance if it determines that the local transportation program developed in the planning process provides for participation by private transportation companies to the maximum extent feasible.

Within the new federal "Safe, Accountable, Flexible and Efficient Transportation Equity Act: A Legacy for Users" (or SAFETEA-LU), there are several proposed changes in the regulations that would strengthen the role of the private sector in the provision of public transportation programs and strengthen FTA's enforcement responsibility. The current rules and requirements related to the protection of private providers of transit from competition with federally assisted transit providers, particularly charter service regulations, are summarized below.

\section{$\underline{\text { Key Definitions }}$}

Following are several of the key definitions included in CFR Section 609.4 that help to determine the applicability of the regulations to organizations and services.

Recipient/Grantee - groups that have received or are receiving federal financial assistance under the Act. This includes subrecipients of a recipient, subrecipients of FTA's state administered programs, public bodies that receive assistance that will be passed on to another public or quasi-public body, and any operator for a recipient, whether publicly or privately owned.

Charter Service - transportation using buses, vans, or facilities funded under The Act for a group of persons who pursuant to a common purpose, under a single contract, at a fixed charge for the vehicles or service to travel together under an itinerary either specified in advance or modified after having left the place of origin. Compensation on the basis of hours of service is evidence of charter operations. The provision of "free" service is not considered relevant in determining if service is charter or mass transportation. 
Mass Transportation - transportation by a conveyance that provides regular and continuing general or special transportation to the public, but does not include school bus, charter, or sightseeing transportation.

Incidental Charter Service - charter service which does not (1) interfere with or detract from the provision of the mass transportation service for which the equipment or facilities were funded under the Act; or (2) does not shorten the mass transportation life of the equipment or facilities. As a general rule, free charter service would be "non-incidental" since it does not recover its fully allocated cost.

Willing and Able - private transportation providers are considered willing and able if they have the desire, the physical capability of providing the categories of revenue vehicles requested and if they possess the legal authority, including the necessary safety certifications, licenses and other legal prerequisites to provide charter service in the area in which it is proposed to be provided.

\section{Compliance Requirements}

The basic premise of the regulation prohibits FTA grantees from using federally funded equipment and facilities to provide charter service except on an incidental basis and when one or more of seven applicable exceptions apply, as described below.

\section{Procedures}

The charter regulations detail the procedures that a grantee must follow to comply with the charter regulations.

At a minimum, if a grantee wishes to provide charter service, it must annually determine if there is a willing and able provider of charter service. The determination process must include a public notice process including:

- Placing a notice in a newspaper of general circulation that describes the charter service that a grantee proposes to provide. FTA allows grantees to describe the services they 
wish to provide in terms of trip purpose. A grantee's notice must include a description of the days, time of day, geographic area, and categories of revenue vehicles for service (but not the capacity or duration of the charter service). Only two categories of vehicles can be specified: buses and vans. A bus is a bus whether it is an intercity bus, a transit bus or a trolley. If a charter customer insists on a particular type of equipment that the willing and able private operator does not have and the grantee does, the grantee still may not provide charter service with that equipment. Further, the grantee cannot lease the trolley to a private operator and claim that the charter service is allowed under the exceptions unless the private operator has exhausted its supply of buses. The "no willing and able" exception applies only if there are not willing and able operators with buses of any kind for charter service.

- Sending a copy of the notice to all private charter service operators in the proposed geographic charter service area and to any private operators that request a notice

- Sending a copy of the notice to the United Motorcoach Association and the American Bus Association

The notices must instruct any operator who wishes to be considered willing and able to submit a statement of its desire and capability to provide the proposed service and proof of its legal authority. Any evidence submitted must be reviewed within 30 days. Within 60 days, a grantee must notify each private charter operator who submitted evidence of the results of the review.

\section{Exceptions}

If the grantee has followed the procedures for public notice described above, then it may provide charter service as long as it qualifies for one of seven exceptions. The exceptions are as follows: 


\section{Exception 1}

This exception applies if no willing and able operator exists. If an operator does exist, a grantee can provide charter service only if the other exceptions apply.

\section{Exception 2}

Providing FTA funded vehicles to private operators to satisfy a capacity need for accessible vehicles is used often by grantees that have vehicles available for charter use by willing and able private operators. Under this exception, a grantee provides service under contract to the private operator, who is responsible for the direction and control of a grantee's vehicle while the service is being provided. A grantee does not contract directly with the public for the service. FTA requires a contract between a private charter operator and a grantee for the provision of equipment and/or service when the private contractor needs extra capacity or accessible equipment. All equipment or services leased under this exception must be incidental (i.e., non-peak period and priced at the fully allocated cost).

\section{Exception 3}

A recipient in a non-urbanized area (population under 50,000 ) may petition FTA for an exception to provide charter service directly to the customer if the charter service provided by the willing and able charter provider would create a hardship on the customer because: the willing and able private operator or operators impose minimum durations pursuant to state regulations and the desired trip length is shorter than the mandatory trip length, or the willing and able private charter operator or operators are located too far from the origin of the charter service.

\section{Exception 4}

Exceptions are granted for events of an extraordinary, special and singular nature. Examples of special events for which exceptions have been granted include the Pan American Games and visits of foreign dignitaries where there were special concerns for attendees' safety and vehicles without undercarriage storage were required. A special events exception requires a grantee to submit its petition to the FTA Administrator at least 90 days prior to the event. The 
petition must describe the event, how it is special, and an explanation of the charter service that private operators are not capable of providing. The Administrator will issue a written decision denying or granting the request.

\section{Exception 5}

This exception allows for the provision of service to government entities or nonprofit agencies serving persons with disabilities or persons receiving public welfare funds. The contracting entity must provide certification that attests to the non-profit nature of the agency, identifies the passengers, declares that the requested charter trip is consistent with the function of the organization and is consistent with Title VI of the Civil Rights Act of 1964.

\section{Exception 6}

A recipient in a non-urbanized area may execute a contract with a government entity or a private, non-profit organization by obtaining a tax-exempt certification from the entity when more than $50 \%$ of the passengers on the charter trip will be elderly, the requested charter trip is consistent with the function and purposes of the organization and the charter trip will be organized and operated in compliance with Title VI of the Civil Rights Act of 1964 as amended.

\section{Exception 7}

A recipient may provide charter service directly to the customer where a formal agreement has been executed between the recipient and all private charter operators it has determined are willing and able, provided the agreement specifically allows the recipient to provide the particular type of charter trip and the recipient has provided for such an agreement in its annual public charter notice. 


\section{Evaluation Of Compliance}

The Federal Transit Administration will consider the following questions to determine if the grantee is providing charter service in compliance with Section 604.9 of the Code of Federal Regulations (CFR):

Has the grantee annually determined if there are any private operators willing and able to provide the service?

If the grantee operates charter service, it is not deficient if it has properly completed the willing and able determination process as described above, it operates charter service under the exceptions, and it has proper documentation of its procedures. If the grantee provides charter service without documentation of a qualified exemption, or inconsistent with the specific provisions of one of the exceptions it is deficient and must immediately cease the provision of illegal charter service.

Is all charter service incidental (service does not interfere with or detract from the provision of mass transportation service, does not shorten the mass transit life of the equipment or facilities, and recovers fully allocated costs)?

The grantee must have documentation to demonstrate the mileage and/or hours are recorded and subtracted from the useful life of the equipment. Any reasonable method of calculation is sufficient. The calculation does not necessarily have to be done for each particular bus; averages can be applied to the entire fleet. The fully allocated cost must be recovered from the charter revenue except in certain circumstances when free services can be provided to economically disadvantaged groups when there is no private operator willing and able to provide the service. 
Is service under the control of the recipient?

The charter service criteria include whether or not the bus transportation is under a single contract at a fixed rate for the vehicle or service. The control of fares and schedules by the other party is a critical element used to distinguish charter service from mass transportation.

Is service designed to benefit the public at large?

Service is designed to benefit the public at large when it serves the needs of the general public, instead of those of a special organization such as a private club. In determining whether service is "open door" FTA considers the level of ridership by the general public, as opposed to a particular group, and attempts to make the service known and available to the public. Published route information (including connections to other transportation routes), posted bus stop signs and head-signs with route numbers and destination information are considered indicators of opportunity for public ridership.

Does the grantee provide charter service with locally owned vehicles? Are the vehicles stored and maintained in an FTA facility?

Charter service may be provided with locally owned equipment if the grantee creates a separate company operated exclusively with local funds or if it keeps its charter accounts completely separate from its mass transit division. If the grantee can not document that charter service is provided with locally owned vehicles and it is physically and financially independent from and receives no benefits from the grantee's provision of mass transit it will be considered deficient. It will be required to cease all charter operations until procedures are in place to keep locally funded charters distinct from mass transit.

The Federal Transit Administration's rules regarding charter services are contained in the Code of Federal Regulations, Title 49, Volume 5, Part 604. Details can be accessed at www.fta.dot.gov. Cite: 49CFR604.1 ${ }^{7}$ 


\section{Summary of Recent FTA Charter Determinations}

The Federal Transit Administration evaluates compliance with charter regulations on a case by case basis after consideration of each particular situation. An excellent summary of past FTA decisions and documents can be found in the Transportation Cooperative Research Program (TCRP) Selected Studies in Transportation Law Volume 7: Transit Charter Bus Service Decisions and Documents, CRP-CD-20. ${ }^{8}$

Following are summaries of recent interpretations of the regulations as they relate to grantee requests to provide incidental charter service under one or more of the seven exceptions and to the concerns of private sector providers:

- The Washington Metropolitan Area Transportation Authority (WMATA) submitted an application to FTA for authorization to provide charter service for the International Transportation Symposium sponsored by the USDOT, the Government of the District of Columbia, and the Greater Washington Board of Trade. Attendees were expected to be foreign transportation ministers, members of Congress, governors, members of Parliament, etc. The Government of the District of Columbia requested public transit buses for the event because they were better able to respond to safety concerns surrounding the Symposium (i.e., no undercarriage storage compartments characteristic of most privately owned buses). WMATA also mentioned in its application to FTA that it had its own Metro Transit and Police Department with extensive experience with special events and heightened security issues. Based on review of the safety and security conditions in connection with the symposium, FTA granted WMATA an exception for this event, provided this would only be incidental charter service that would not detract or interfere with mass transit use and would not shorten the life of FTA funded facilities or equipment.

- The Indianapolis Public Transportation Corporation (IndyGO) requested a waiver to provide charter services for the World Police \& Fire Games, which was expected to draw approximately 10,000 individuals. IndyGo submitted its request based on its belief that private providers had inadequate capacity for this event. Two private providers disagreed in their complaint to FTA. Consequently, FTA denied the exception based on 
the fact that IndyGo was unable to provide sufficient evidence to support its claim of private provider capacity constraints.

- The Kansas City Area Transportation Authority (KCATA) submitted a request to provide charter service to the American Dental Association Convention for the purpose of transporting conventioneers to restaurants and entertainment areas throughout the city. While FTA will grant exceptions for "events of an extraordinary, special or singular nature," it determined this convention was not an event of a singular nature since it is held periodically and only the locations within the United States change. FTA recommended that KCATA follow the normal public participation process and, if it determined there were no willing and able private providers, it could offer the charter service as long as it was incidental in nature. Following the public participation process, it was determined that private providers in the area did not have capacity to provide this service because they were already providing other services related to the convention. Consequently, an exception was granted.

- Based on security concerns, the White House requested that Chicago suburban transit provider Pace provide 35 buses to transport approximately 4,000 airline employees to a White House event in the Chicago area featuring the Secretary of Transportation. The buses were used for approximately two hours and Pace was reimbursed for its costs. Although FTA concluded that this service would probably have qualified for an exception, since Pace did not petition the administrator for an exception based on the type of event, the special circumstances and/or private provider capacity constraints, it was in violation of 49 CFR Section 609.4.

- The FTA granted an exception to the Lowell Regional Transit Authority (LRTA) based on its application to provide a 25+ passenger compressed natural gas (CNG) bus to transport Senate staff to various press events related to a two day environmental tour. LRTA did contact three private providers who indicated they did not have the capacity to provide the necessary services. FTA granted the exception based on its findings that this was an event of an extraordinary and singular nature. However, it did remind LRTA that the special event exception process required the recipient to submit its request for an 
exception at least 90 days prior to the event, and that any exception granted was only for the particular event specified.

- The FTA granted the Greater Cleveland Regional Transit Authority (RTA) an exception based on its application to provide service for the U.S. Department of Veterans Administration (VA). The VA needed approximately 20 buses temporarily outfitted to provide additional wheelchair capacity. In its application, the VA stated it was a government entity, there would be a significant number of physically-challenged passengers, the trip was consistent with the functions and purpose of the VA, and the service would be incidental.

- The Detroit Department of Transportation (DDOT) requested, and was granted, a special event charter exception so it could provide service for the G-8 Energy Summit. Attendees were expected to include energy ministers from around the world. The FTA recognized the special safety concerns and the need for vehicles that do not have undercarriage storage.

- The San Diego Metropolitan Transit Development Board (MTDB) requested an exception to charter regulations so that it could provide transportation for the NFL Super Bowl XXXVII. The exception was granted based on the fact that the service was considered incidental and the public participation process had been followed.

- The Metropolitan Transit Authority (Houston METRO) requested a special charter exception so that it could provide service for the 2004 Super Bowl and related activities. As part of the determination process, the FTA notified the American Bus Association and the United Motorcoach Association to determine the private sector's capacity to provide service for the event. Several private operators objected on grounds that Houston Metro did not notify and/or adequately evaluate the capacity of private operators. The FTA's charter regulations do not prescribe a specific procedure or manner in which the capability of private providers is determined. Although it was argued that METRO should have contacted the private providers individually to assess their capability, FTA determined that, based on comparable historical data provided by the National Football League with respect to other cities that have hosted the Super Bowl, the demand for 
services up to and including the event would require 800-900 buses. Also, since METRO had considerable experience coordinating transportation with private providers and was familiar with their fleets, it recognized that private charter operators could only provide approximately 500-600 buses. METRO also provided assurance to the FTA that it would use private operators to the maximum extent feasible. FTA determined that the needs exceeded private provider capacity and granted the exception.

- The Hillsborough Area Transit Authority (HARTline) provided nine of twenty buses requested by the White House to provide transportation to support the President's "Briefing of the Troops." The buses were used to transport media and military families from MacDill Air Force Base to an outside hangar. The buses were used for an eight hour period, and HARTline was reimbursed for its costs. For security reasons, the White House specifically requested HARTline buses and required background checks on all drivers. Although FTA was aware that this was a special request with a very narrow time frame, it indicated that if the request had been made prior to the provision of services it probably would have qualified as an exception and the FTA would have responded to a written or verbal request expeditiously. FTA indicated that, since the service was not open to the public and federally-funded equipment was used to provide service for a specific group of individuals, an exception should have been requested. 


\section{Chapter Five}

\section{Best Practices and Guidelines}

\section{Overview}

Chapter Five provides a summary of current practices related to the provision of special event transportation services. The findings of this chapter are based on field observations, discussions and interviews with agency staff involved in special event services, and a review of existing literature on this subject. Best practices in planning guidelines and strategies are presented for use by transit agencies to enhance their involvement in community planned special events.

\section{$\underline{\text { Research Methodology }}$}

A series of activities were undertaken in the development of the best practices and guidelines for the provision of special event transportation services included in this chapter.

A thorough literature review revealed a number of reports and plans for special events with a focus on engineering and technology applications used to control traffic flow. Very little if any consideration was given to transit in mitigating the congestion often associated with special events. This suggests there may be opportunities for transit to elevate its role in planning and coordinating with other stakeholder agencies (law enforcement, public works, emergency services, etc.) that also have specific responsibilities for special events.

Interviews and discussions with agency staff with extensive experience in planning and implementing the transit elements of special event transportation services as well as a review of existing service plans are the basis for the guidelines that follow. These included the Jacksonville Transportation Authority (JTA), which recently provided a variety of services for events leading up to and including Super BowI XXXIX, and VOTRAN, which has a long history in special event services, ranging from large events such as the Daytona 500 and the Pepsi 400, to smaller events such as the Manatee Festival. Representatives from LYNX, the public transit provider for the greater Orlando area, assisted in the development of these guidelines based on their experience with the Citrus Bowl and World Cup Soccer. Sarasota County Area Transit (SCAT) and Hillsborough Area Regional Transit (HARTline) staff also offered advice 
based on their experience with events such as the Gasparilla Festival, the Florida State Fair, the Offshore Boat Races, and Professional Golfers Association of America (PGA) tournaments.

Information collected during the Center for Urban Transportation Research's staff participation in the First National Conference on Managing Travel for Planned Special Events in December 2004 and the Florida Public Transit Association's 2005 Annual Conference offered additional insight into special events transportation in San Diego, Washington, Los Angeles, New York City, and Chicago, as well as several Florida locations.

On-site field observations of the shuttle services operated by LYNX for the 2005 Florida Classic Football game in Orlando were incorporated in the development of the guidelines and best practices.

Finally, the research team's experience in planning and managing special event transit services for a wide range of events provided real life experiences and lessons learned.

\section{Guidelines and Best Practices}

These guidelines and best practices were developed to offer an overview of the steps a transit agency should follow for planning and operating special event transportation services. The steps are grouped into seven categories ranging from the preliminary consideration of providing special event transportation services through post-event activities. Due to the unique characteristics of each special event service related to capacity requirements, operating environment (facilities, roadway configuration), and agency resources and capabilities, only certain guidelines will apply to each event.

\section{Policy and Procedure}

The agency should first determine the governing board's policy on the provision of special event transportation services. As noted in the summary of the survey results, some agencies have made the decision not to entertain requests for services to avoid non-compliance with charter regulations or because they believe there is adequate private provider capacity. If the policy board allows for the provision of services, the approval process should be determined. Some 
agencies are required to seek approval for each event, while others may have to get approval only for services that exceed a certain threshold.

An internal decision process similar to the one detailed in Chapter Three should be developed, with consideration given to the agency's goals related to need, cost effectiveness, patronage potential, partnership opportunities, and compliance with charter regulations. This process should involve representatives from functional areas such as maintenance, operations, administration, and marketing who could be impacted by the service. An application process should be developed to ensure the agency has sufficient time to evaluate the sponsor's request and secure all of the information necessary to plan for the service including dates/times, expected patronage, coordination requirements (law enforcement, emergency services, traffic engineering, etc.) and promotional opportunities/requirements.

The agency should determine what types of services are appropriate to best serve the special event. Some may be adequately served with enhancements to existing services (additional vehicles on existing routes or expanded services hours), while others may require park-and-ride shuttles, new routes, or a combination of several service types. When used, the park-and-ride lots should be located within a 20-minute travel time of the event to permit quick turn-around of the vehicles, permitting a maximum utilization of the assigned vehicles and operators.

An important part of the evaluation process relates to the agency's capacity. To be in compliance with FTA regulations, the requested service can only be "incidental" in that it does not detract from the services normally provided by the agency. For example, an agency may not have support staff or vehicles available to provide service for a special event if it is scheduled to occur during peak hours on a weekday.

Another potential capacity constraint for Florida transit agencies is related to safety, as described in Florida DOT Rule Chapter 14-90.006, Florida Administrative Code (FAC), Equipment and Operational Safety Standards Governing Public-Sector Bus Systems. Drivers are not permitted to drive more than 12 hours in any 24-hour period or drive after having been on duty for 16 hours in a 24-hour period. Drivers also are not permitted to be on duty more than 72 hours in any period of seven consecutive days. If the driver has reached the maximum of 72 hours of on duty time during the seven consecutive days, a minimum of 24 hours of off-duty 
time must be provided. This requirement has posed a particular challenge for transit operators who have been asked to support a large out-of-town event, considering the departure time from the "home" property to arrival at the "host" property and the in-service time requirements. Those interviewed also recommended a 1 to 10 ratio of supervisors to vehicles when using out of town resources, which may further impact the capacity of existing personnel.

If applicable, the transit operator must evaluate its collective bargaining agreement for any additional stipulations related to schedules (holidays, seniority, part-time employees, and pay rates) when evaluating its capacity and associated expenses.

\section{Planning and Coordination}

Once the decision to operate the special event service is made, service planning efforts begin based on the evaluation of the appropriate service mix. This may be a minimal effort if only enhancements to existing services are necessary. If shuttles or new routes are needed, a much more detailed service plan must be developed, which may include:

- Route definition

- Boarding and alighting locations at origin and destination

- Accommodations for pedestrian activity

- Evaluation of roadway widths and turning radii

- Identification of park-and-ride facilities

- Design of automobile and bus access and egress points

- Identification of vehicle staging areas

- Vehicle and facility accessibility considerations

It is in this phase of planning that the importance of coordination with other agencies first becomes apparent. Nearly every decision related to route design, facility siting, and enforcement must have the buy-in of event organizers, local traffic operations, and law enforcement personnel from the early stages of planning up to and including the special event.

Without exception, staff from transit agencies involved in large special events that were interviewed for this report stated that coordination with other agencies was the key to effective service delivery. It was interesting to note, however, that, when asked how they worked to 
ensure coordination and cooperation, none could offer any recipe for success (with the exception of one who said they get cooperation because they make sure the field staff "always gets fed"). When pressed, it became apparent that the relationships that resulted in good coordination did not have much to do with the special event itself but had been nurtured through cooperation over time. Examples of cooperation include transit's prompt response to a request for assistance with the evacuation of a flooded nursing home, the identification and safe return of a missing child by an alert bus driver, and a transit authority's willingness to participate in a program similar to Neighborhood Watch by reporting suspicious activities noted along their routes. Similarly, the transit agency staff's involvement in their community's Emergency Operations Center's activities contributes greatly to building these interagency and interpersonal relationships.

It is important that coordination occurs between the event sponsor and the transit agency, particularly in communities with detailed special event permitting processes. An example of a very detailed special event permit application from Louisville, Kentucky is included as Appendix B. Often the initial permit application must include information about items that a transit agency may require such as temporary structures, electricity, signage, and barricades. The transit provider should not assume that the event sponsor understands the particular transit needs of a special event. These should be communicated in the initial planning stages of the special event.

Additional coordination between the transit agency and charter bus operators may also be useful to eliminate potential interference with their respective services. A situation was observed where a charter bus that was lost or unable to get to an event drove into the shuttle location, interfering with the flow of public buses at the site and causing a sudden surge in the number of passengers trying to board the shuttle. 


\section{Operations}

Again, the complexity of the operational aspects of a special event will vary based on the particular event, but the following items should be considered, and many should be incorporated in the agency's operating plan. Appendix C includes several examples of transit system operating plans.

Vehicle assignments - Identify the specific vehicles that will be used as well as where and when they should report both pre-event and post-event. This includes transit vehicles and support vehicles such as maintenance and tow trucks.

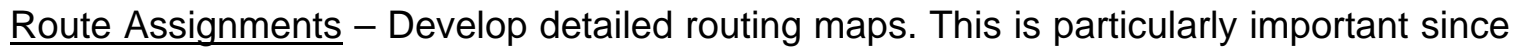
the drivers working on special event services may be new, or in the case of an agency providing support for an out of town event, completely unfamiliar with the area.

Employee Assignments - Determine the number and type of employees needed to support the event. These may include drivers, supervisors, mechanics and administrative/customer service personnel. Be sure to include a sufficient number of staff to accommodate breaks, meals, shift changes and the safety standards related to driver work hours previously outlined. When the specific individuals are assigned, contact information should be collected and disseminated (e.g., telephone numbers, cell numbers, e-mail addresses, etc.).

Signage - Developing directional and informational signage and their appropriate placement may be a responsibility shared by the local jurisdiction, the event sponsor, and the transit operator. Regardless of who is responsible, this effort should be well coordinated, as several of those interviewed indicated good signage was an essential element of successful special event services. In one instance, a lack of communication regarding signage resulted in a delay in bus boardings. A well intentioned city worker placed a sign quite some distance from the boarding location that listed personal articles (umbrellas, coolers, video cameras, etc.) that were prohibited in the event venue. Many of the pedestrians did not see the sign, and the bus operators were put in a position of having to inform the passengers of the prohibitions as they boarded the bus. At that 
point, many were forced to get off the bus to return personal possessions to their vehicles. Such signs should be placed in multiple locations, including at the entrance of the parking lot.

It is important not to lose sight of the fact that special event attendees may be unfamiliar with the area or unaccustomed to using transit, so signs should be plentiful and simple to understand. Off-site signs such as variable message boards can be used effectively along major roadways to notify individuals of the upcoming event, the potential for congestion associated with the event, or the availability of park-and-ride facilities, for example. On-site signage can be used to direct attendees to the event venue, designated parking locations, transit access locations, and pedestrian paths.

Security - While most of the agency representatives interviewed recommended that the most efficient way to secure payment for the services was to develop the fully allocated cost and invoice the sponsor (who, in turn, may build the cost of transportation into the event ticket price) based on the hours of service, some situations call for the use of tickets or cash for fare payment. Not only are there additional costs associated with cash handling, but it also calls for a number of security measures that would otherwise be unnecessary. Easily identifiable security personnel should be stationed near a location where cash transactions are taking place to discourage a would-be thief. Sales personnel should not have more than the minimum amount of cash required to complete transactions on their person at any given time. Consideration should be given to a periodic collection of the cash for transfer to a secure location such as an on-site secure vehicle or an off-site vault. In addition, there should be built-in safeguards for the accountability of the staff involved in the cash transactions. A minimum amount of cash should be in their possession at any given time and there should be a mechanism for a proper accounting of the transactions such as numbering the tickets and recording tickets distributed, sold and returned.

When planning for special event transportation, the transit agency should take into consideration any special security that may be imposed by event organizers and law enforcement. This could include security checks on all bus operators and vehicles entering certain restricted areas adjoining the event. All transit agency personnel may 
need valid agency identification, as well as picture identification including a valid driver's license. Agency buses may be required to conduct security checks, including undercarriage examinations. All security requirements should be incorporated in the agency's operating plans. The agency should account for the additional time and resources required as a result of security requirements.

Equipment and Supply Requirements - To ensure efficient operations and the safety and comfort of the employees and passengers, the following items should be available where appropriate:

- Portable microphones

- Flashlights/batteries

- Fully charged radios/cell phones and back-up batteries

- Reflective vests

- Trash receptacles

- Food and refreshments

- Restroom facilities

- First aid supplies

- Adequate lighting

- Easily identifiable clothing for transit staff

\section{Boarding and Alighting}

Several recommendations regarding vehicle loading were provided by the agency representatives interviewed. Maintaining an even flow of buses arriving and departing versus a number of vehicles all loading and departing at the same time was perceived to have a positive psychological effect on the passengers. Similarly, the use of serpentine lines for bus boardings as opposed to a long straight queue seems to put passengers at ease and confident they will arrive at the event on time. Cordoning the area so passengers are funneled directly to the loading gate was observed to enhance the flow of boardings as was the policy of quickly loading and dispatching one bus at a time. 
When evaluating accessibility, the boarding and alighting locations should accommodate wheelchairs and other mobility devices. One suggestion was to provide special needs transportation from a separate location with specialized vehicles. If that is not feasible and the specialized transportation must be used to provide the regular fixed route service, it was recommended that special needs passengers, specifically any wheelchair passengers, be loaded on the second bus in the queue. This permits the loading and securement of the wheelchairs prior to the mass loading of the ambulatory passengers.

It is very important for the transit agency to work closely with security and law enforcement personnel to make sure the travel ways for the buses to and from the boarding and alighting areas are kept clear and unimpeded. For events with large numbers of people requiring transportation, security and law enforcement personnel can aid in keeping the passenger loading orderly.

\section{Communications}

Good internal and external communication capabilities are important to special event transportation services. Whether it is a small event that requires communication between a driver and a street supervisor or a large event where communication is required between a central command station and the transit system's central dispatch office, particular attention should be give to this component of the operation.

As previously mentioned, cell phones, radios, and back-up power supplies may be all that are necessary for a small event. Radio and cell phone reception in the event area should be checked prior to the event. If reception is substandard, supplemental communications such as satellite telephones should be considered. For larger events, the tools and personnel required for communication between the central dispatch office and on-site supervisors are important. For very large events, the ability to use a common radio channel for communication between various agencies involved in the special event makes it easier to monitor all aspects of the event and promptly respond to unexpected situations.

Wide circulation of the operations plans (such as those examples included in Appendix C) internally and externally will also enhance communications. The roles and responsibilities can 
be clearly defined in the plan so, if there is a need to address an issue at a particular location, the appropriate supervisor or law enforcement agency can be easily identified and contacted.

Another important component of communications is that which must take place between the transit agency and passengers who use the regular service, those who will use the special event services, and the residents and businesses who will be impacted by the special event.

First, it is important that the transit operator notify its existing customers of any service changes or detours that will occur as a result of the event so they can plan their trip accordingly. Notices should be posted on-board the buses, at transit facilities, on the agency website, and used in conjunction with well informed customer service personnel who can fulfill this need.

It is important to communicate with the passengers being transported. This could range from verbal instructions as they first board the bus to distribution of printed hand-outs. Printed materials could include information on the event itself, locations and instructions for boarding the bus on the return trip, the hours of transportation services, and contact information for questions, lost and found, etc. Information should be provided in multiple languages as necessary.

Information that needs to be shared with event attendees can be communicated with signage, via the transit agency website, and with on-site transit "ambassadors" who can provide directions and instructions related to the special services. This information should focus not only on the special service but also the regular transit service the attendees can take advantage of. Depending on the nature of the event, there may be a number of opportunities to use the communication channels established by the event sponsor to disseminate information. The sponsor may be using television, radio, public service announcements, and print media to promote the event. Through coordination with the sponsor, these media can also be used to communicate and educate the public about available transportation services.

Finally, the transit provider may need to play a role in communicating with area residents and businesses about the potential impacts the event may have. This may be something as simple as providing notification of street closures that may be necessary to accommodate the transit services. For large events with the potential for significant impacts, it may be necessary to 
develop an information campaign that might include specialized information about existing services that employees can use instead of their personal vehicles for commuting purposes, assistance in identifying carpool opportunities, developing alternative parking strategies, or encouraging businesses to allow employees to telecommute when the event takes place.

\section{Data Collection}

To comply with federal regulations and to assist the transit operator plan for future special events, data should be collected during the event. As mentioned in Chapter Four, special event services can be provided only if they do not detract from the useful life of the vehicle. Therefore, data related to the number of miles traveled and/or hours of service provided must be calculated and deducted so the agency can establish the appropriate intervals for vehicle retirement. This type of information may be required by the event sponsor if they have agreed to reimburse the agency for costs based on any of these measures.

Another benefit of collecting these data is their use for planning activities. In the very short term, if the fareboxes are utilized for passenger counts for trips to the event, this information can be downloaded during the event and appropriate adjustments can be made for post-event services. In the long term, the data can be used to evaluate future requests for this type of service to determine if the service fulfills agency objectives, if sufficient resources are available to provide the service, and what types of service and schedules are appropriate for this type of event.

\section{Post-Event Debriefing}

Post-event debriefings are another valuable planning tool. At the conclusion of each special event, transit agency representatives should evaluate their performance to determine what worked and what did not and incorporate the lessons learned in future special event service planning. It is also valuable to ascertain the transit agency's performance from the perspective of other agencies involved in the special event. Brief reports should be compiled and filed for future reference. 


\section{References}

${ }^{1}$ NCHRP Synthesis 309, "Transportation Planning and Management for Special Events - A Synthesis of Highway Practice," Transportation Research Board, 2003.

${ }^{2}$ FHWA-OP-04-010, "Managing Travel for Planned Special Events," Federal Highway Administration, September 2003.

${ }^{3}$ FHWA Office of Operations Planned Special Events Management website, http://www.ops.fhwa.dot.gov/program_areas/sp-evnts-mgmt.htm

${ }^{4}$ FHWA Office of Operations "Planned Special Events Management website, http://www.ops.fhwa.dot.gov/program_areas/sp-events-mgmt/fact_sheet

${ }^{5}$ FHWA Office of Operations Planned Special Events Management website, http://www.ops.fhwa.dot.gov/program_areas/sp-events-mgmt/faq

${ }^{6}$ HARTline Special Service Event Department's Special Event Process

${ }^{7}$ The Federal Transit Administration's rules regarding charter services are contained in the Code of Federal Regulations, Title 49, Volume 5, Part 604. Details can be accessed at www.fta.dot.gov. Cite: 49CFR604.1

${ }^{8}$ Transportation Research Board Transit Cooperative Research Program, CRP-CD-20, Selected Studies in Transportation Law, Volume 7, Transit Charter Bus Service Decisions and Documents, 2005. 


\title{
Special Events Appendices
}

\author{
Disregard this first sheet
}




\section{Appendices}

Appendix A Survey Instrument

Appendix B Louisville Metro Special Event Permit Application

Appendix C Sample Service Plans

C-1 JTA Jacksonville Super Bowl XXXIX

C-2 VOTRAN Pepsi 400 Winston Cup Series Race

C-3 LYNX Florida Classic

C-4 Chicago Transit Authority (CTA) Taste of Chicago 
Appendix A

Survey Instrument 


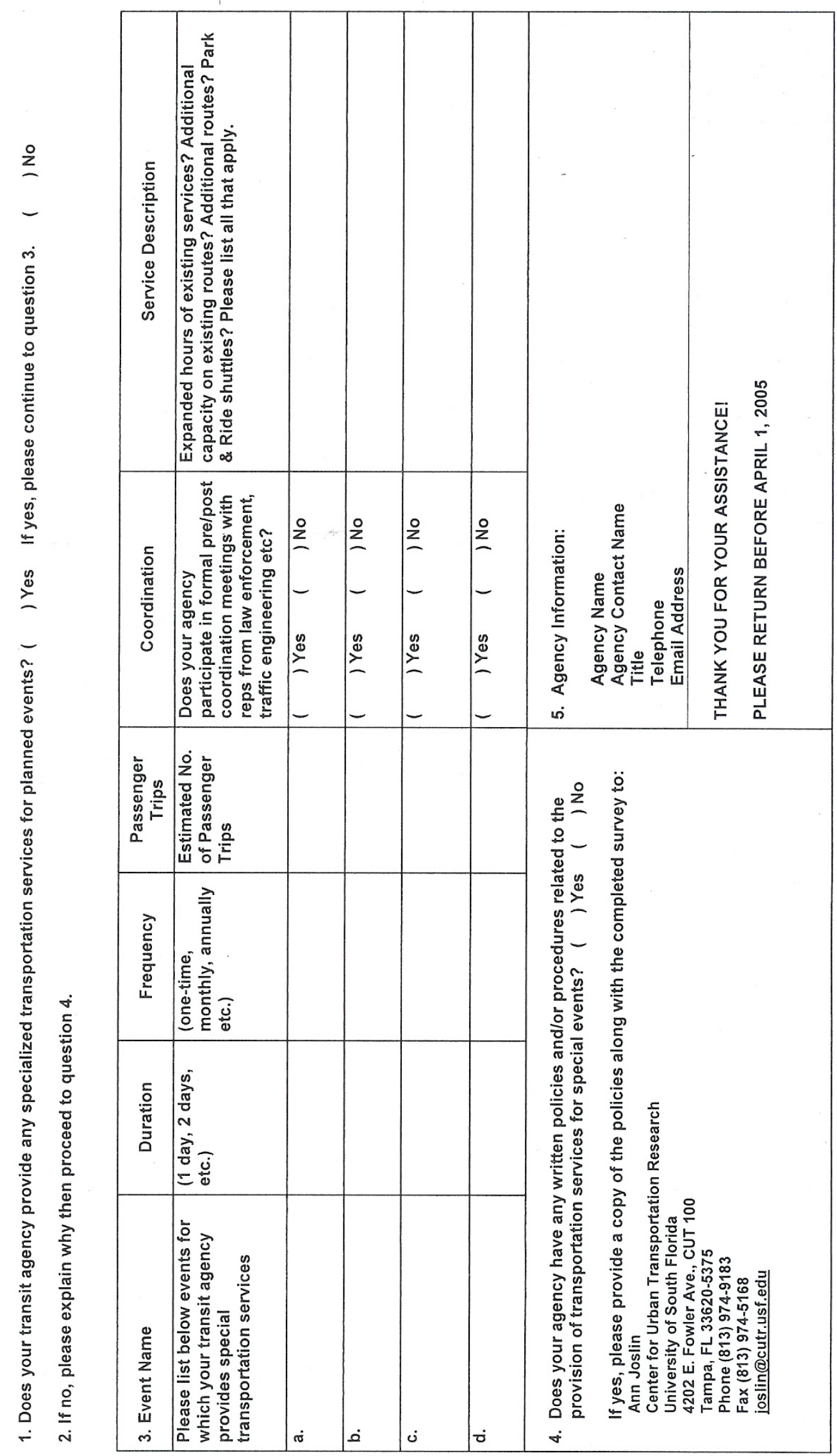


Appendix B

Louisville Metro Special Event Permit Application 


\section{LOUISVILLE METRO SPECIAL EVENT PERMIT APPLICATION}

Event Name:

Official name of festival or event (name used to advertise event)

Event Producer:

Name of individual, group or organization producing event, or agency with whom event is contracting

Primary Contact:

Person who should be contacted regarding the application, event or in case of an emergency

Contact Address:

Street Mailing Address

City

State Zip

Primary Contact Information:

\begin{tabular}{lll}
\hline Day Phone & Cell Phone Night Phone
\end{tabular}

E-mail

Web site

Fax

EVENT TYPE - Events with 500 people or less, Block Parties, Parades or Walks/Runs/Races, submit a SMALL EVENT \& PARADE PERMIT. Events with 500 people or more check the box(es) below that best describe your Special Event.

$\square$ Major Festival or Event (maximum peak attendance of 5000 or more people) - $\$ 25$

$\square$ Medium-Size Festival or Event (maximum peak attendance between 500 and 5000 people) - $\$ 20$

$\square$ Small Event, Block Party - \$15; Submit small event permit if maximum peak attendance is under 500 people

$\neg$ Parade - \$10; Submit small event permit if maximum peak attendance is under 500 people

$\square$ Walk/Run/Race - \$10; Submit small event permit if maximum peak attendance is under 500 people

$\neg$ Rally/Public Gathering - $\$ 10$; Submit small event permit if maximum peak attendance is under 500 people

$\square$ Film/Commercial Shoot - $\$ 10$

$\square$ Other

$\square$ Describe any special or unusual features of your event:

SPECIAL EVENT LOCATION - Venue and address of event: Date(s) and Time(s) of Event (include Load-In and Load-Out/Clean-Up)

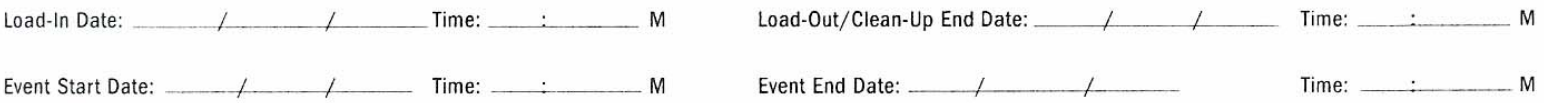

Total attendance expected: Peak attendance expected at any one time:

Rain/Cancellation Policy: Provide alternative dates, times and locations of event, if applicable.

STREET CLOSINGS - List streets to be closed for Special Event (See Street Closings, Section 20, Special Events Handbook)

If a state road will be closed, apply for a Street Closing Permit from the Kentucky Transportation Cabinet (See Contact List, Section 24, Special Events Handbook)

Street Closings to begin on: Date: - Time: M Re-opening on: Date: M

NOTE: Louisville Metro will notify TARC if bus or trolley re-routing is going to be necessary. Event Producers must notify affected businesses and residents of street closures. Event Producers must provide barricades for street Closings. Check Yellow Pages under "Barricades."

SPECIAL PARKING RESTRICTIONS - Describe parking restrictions or requirements needed for Special Event (See Street Closings, Section 20; Barricades, Section 4; Security, Section 17, Special Events Handbook)

Number of meters to be bagged: Identification numbers $0 \mathrm{~N}$ meters

"No Parking" signs placement - list street(s) and block numbers where to install

(Attach sperate sheet with meter numbers if needed) 
TRAFFIC CONTROL - Describe traffic control needed for Special Event, number of officers requested, etc.

ADDITIONAL REQUESTS

\section{ADDITIONAL EVENT FEATURES}

Review the checklist of possible event features below and check all that apply to your event:

${ }^{1}$ Requires submission of Insurance Information Form ${ }_{2}^{2}$ May involve a fee ${ }_{3}^{3}$ Requires special license or permit application and fee

$\square$ Alcoholic Beverages Served / Sold ${ }^{1,2,3}$ (See Alcoholic Beverage Control, Section 3, Special Events Handbook)

$\square$ Restroom Facilities (See Restroom Facilities, Section 16, Special Events Handbook)

$\square$ Carnival Rides/ Inflatables ${ }^{1}$ (See Carnival Rides and Inflatables, Section 6, Special Events Handbook)

$\square$ Security $^{2}$ (See Security, Section 17 , Special Events Handbook)

$\square$ City Stage Rental ${ }^{2}$ (See Rentals/ Event Services, Section 15, Special Events Handbook)

$\square$ Cleaning - City Assisted ${ }^{2}$ (See Clean-Up Plans, Section 8, Special Event Handbook)

$\square$ Signs/Banners ${ }^{2}$ (See Signs and Banners, Section 18, Special Event Handbook)

$\square$ Electrical Service - Temporary ${ }^{2}$ (See Electrical Services, Section 9, Special Event Handbook)

$\square$ Emergency Medical Services ${ }^{2}$ (See Emergency Medical Services, Section 10, Special Event Handbook)

$\square$ Tent(s) Over $200 \mathrm{sq} \mathrm{ft}{ }^{3}$ (See Tents and Temporary Structures, Section 21, Special Event Handbook)

$\square$ Fireworks Display ${ }^{1,2,3}$ (See Fireworks and Pyrotechnic Displays, Section 11, Special Event Handbook)

$\square$ Vendors ${ }^{3}$ (See Vending, Location Use and Personal Conveyance Permits, Section 22, Special Event Handbook)

ALCOHOLIC BEVERAGES (See Alcoholic Beverage Control, Section 3, Special Events Handbook)

If you are serving or selling alcoholic beverages at your event, a Louisville Metro and Kentucky State temporary alcoholic beverage license will be required. You must complete the $A B C$ applications and submit them with payment to the State ABC and Louisville Metro $A B C$, along with proof of insurance, at least 30 days before an event date.

Alcoholic beverage concessionaire or caterer:

Insurance company:

Contact:

Office Phone:

CLEAN-UP PLANS AND PROCEDURES (See Clean-Up Plans, Section 8, Special Events Handbook)

Event producers holding an event on Louisville Metro properties, facilities, streets or right-of-ways are responsible for clean-up and removal of debris from the area and all adjacent property affected, including sidewalks, steps, yards and alcoves.

Clean-up coordinator:

Company Name:

Office Phone:

Cell Phone:

Email:

Event producer will provide dumpsters:

Event producer will provide trash containers:

Would you like Louisville Metro to provide dumpsters and trash containers? $\square$ Yes $\square$ No (NOTE: A fee may be charged for containers)

Number of dumpsters: Number of trash containers: Number of trash liners

Drop-off date: Time: $\quad$ : $\quad$ M

Pick-up date: Time: M

Exact location where containers should be dropped: (Indicate on site map if necessary)

ELECTRICAL SERVICES (See Electrical Services, Section 9, Special Events Handbook) How will electrical service be supplied $\square$ Generator $\square$ Public Utilities

Electrical contractor/supplier: Both

Emergency contact name:

Office Phone: 
EMERGENCY MEDICAL SERVICES (See Emergency Medical Services, Section 10, Special Events Handbook) Emergency Medical Services must be provided at all events defined as a "Major Event." A minimum of one team for an attendance up to 5,000; two teams for an attendance up to 15,000; and three teams for an attendance up to 34,000 or greater is required.

Is the event producer providing private Emergency Medical Service? $\square$ Yes $\square$ No IF YES, complete information below:

Provider: Office phone: Cell phone:

Briefly describe your event's Emergency Medical Services plan:

Do you want to request dedicated Emergency Medical Service unit(s) from Louisville Metro? $\square$ Yes $\square$ No

If YES, how many units? (NOTE: A fee may charged for dedicated units)

FIREWORKS/PYROTECHNICS INDOOR \& OUTDOOR DISPLAYS (See Fireworks/ Pyrotechnics, Section 11, Events Handbook) An application from the Fire Marshal, provided by IPL (Louisville Metro Inspections, Permits \& Licenses, $444 \mathrm{~S}$. 5th Street, Suite 101, Louisville KY $40202-4314$, (502) $574-2985$ or (502) 574-4218) must be submitted along with a $\$ 175$ non-refundable fee and proof of insurance at least 30 days before the event. Fireworks/pyrotechnics display vendor:

Contact name: Office phone:

E-mail address: Cell phone:

METRO STAGE RENTAL (See Rentals/ Event Services, Section 15 of the Special Events Handbook)

Stage Location - indicate on attached site map. Dates requested for the Louisville Metro Stage, IF AVAILABLE.

Drop-off date: , , Time: : M Pick-up date: $\_, /,$Time: $\_$M

RESTROOM FACILITIES (See Restroom Facilities, Section 16, Special Events Handbook) NOTE: Louisville Metro does NOT provide portable restroom facilities for events.

Number of permanent facilities at event location: Number of portable facilities:

Name of supplying company: Office phone:

Emergency contact name:

Cell phone:

SECURITY (See Security, Section 17 of the Special Events Handbook) NOTE: Event producers must provide adequate security for event management and crowd control

Total number of private security personnel or off-duty law-enforcement officers on-site:

Organization providing security:

Contact name: Cell phone:

Types of security being provided by the Event Producer(s):
$\neg$ Beer/Alcohol Sales Security
$\neg$ Event Area Security
$\neg$ Gate Security
$\neg$ Money Handling Security
$\neg$ Event Area Security
$\square$ Stage Security

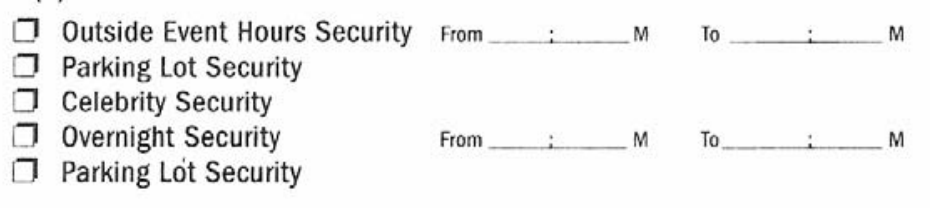

Describe your event's security plan: 
SIGNS/BANNERS (See Signs and Banners, Section 18, Special Events Handbook)

Number of signs ___ Number of banners

Location of signs/banners to be installed

TENT(S) (See Tents and Temporary Structures, Section 21 of the Special Events Handbook)

Enclosed tents over $200 \mathrm{sq}$. ft. require a permit. ALL tents over $400 \mathrm{sq}$. ft require a permit.

Contact Louisville Metro IPL, 444 South. 5th Street, Suite, 101, Louisville, KY 40202, (502) 574-3321.

VENDORS (See Vending, Location Use and Personal Conveyance Permits, Section 22 of the Special Events Handbook)

An event that will have food or merchandise vendors must apply for a Temporary Master Location Use Permit. A Personal

Conveyance Permit is also required for each vendor booth or mobile vendor. A map of the location of all vendors must be attached.

Vendors selling food and drink (other than prepackaged) also require a permit from the Health Department.

SITE MAP REQUIREMENT - (See Site Maps, Section 19, Special Events Handbook)

Regardless of an event's location, a Site Map must be submitted to IPL with this permit, showing the location of the event; all streets, alleys and rights of way affected by the event and detailing specific event features and equipment.

INSURANCE REQUIREMENTS - (See Insurance, Section 13, Special Events Handbook).

Proof of insurance is required from an event producer and event subcontractors, at least 30 days prior to an event, if estimated attendance at an event is 500 or more people or if the event will include carnival rides, fireworks, or selling/serving alcoholic beverages. The enclosed list of Insurance Requirements should be reviewed immediately with your insurance agent in order to comply. Please have your insurance agent complete this Insurance Certificate form, (or the Accord form) and return it with your application, and obtain and forward required Certificates of Insurance from all subcontractors referenced above.

\section{HOLD HARMLESS AND INDEMNIFICATION CLAUSE}

The Applicant/Event Producer shall indemnify, hold harmless and defend Louisville Metro Government and the Waterfront Development Corporation (if event is held on Waterfront Park Venues), their elected and appointed officials, employees, agents and successors in interest from all claims, damages, losses and expenses including attorneys' fees, arising out of or resulting, directly or indirectly, from the Applicant/Event Producer's (or Applicant/Event Producer's subcontractors, if any) performance or breach of the contract provided that such claim, damage, loss, or expense is: (1) attributable to personal injury, bodily injury, sickness, death, or to injury to or destruction of property, including the loss of use resulting there-from, or breach of contract, and (2) not caused by the negligent act or omission or willful misconduct of Louisville Metro Government or the Waterfront Development Corporation, their elected and appointed officials and employees acting within the scope of their employment. This Hold Harmless and Indemnification Clause shall in no way be limited by any financial responsibility or insurance requirements and shall survive the termination of this Special Event Permit Application.

Only applicants in good standing with Louisville Metro will be considered for approval. Any misrepresentation in this application or deviation from the final approved specifications and activities described herein or failure to abide by all Federal, State and Louisville Metro Laws, ordinances, policies and procedures may result in the immediate revocation of the approved permit and/or refusal to issue a permit in the future.

$\mathrm{X}$

Signature of the agent duly authorized by the Special Event Permit applicant to bind it.
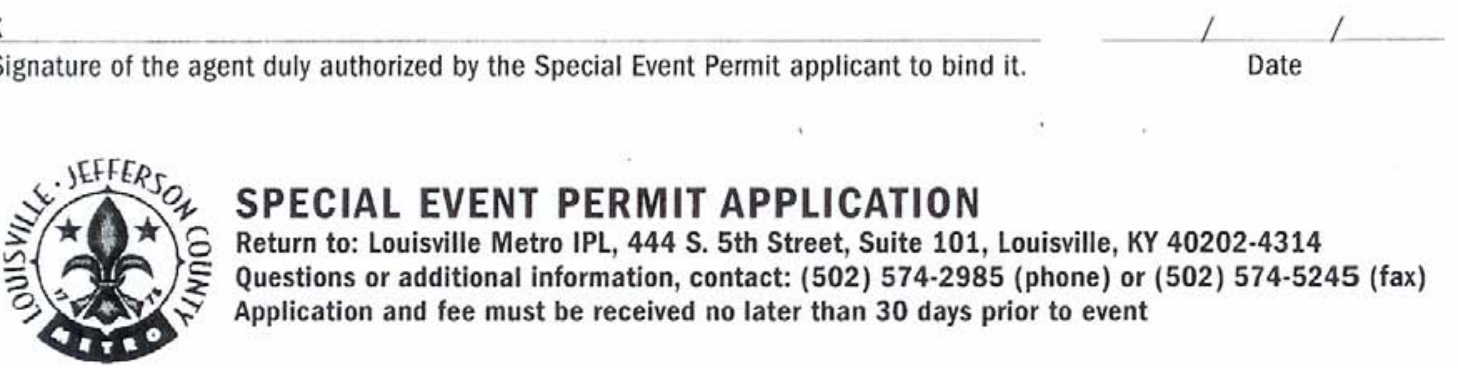

SPECIAL EVENT PERMIT APPLICATION

Return to: Louisville Metro IPL, 444 S. 5th Street, Suite 101, Louisville, KY 40202-4314

Questions or additional information, contact: (502) 574-2985 (phone) or (502) 574-5245 (fax)

Application and fee must be received no later than $\mathbf{3 0}$ days prior to event 


\section{SMALL EVENT PERMIT APPLICATION}

For events, block parties, parades, walks, nuns and public rallies with a maximum peak attendance under 500 people

Return to: Louisville Metro IPL, 444 S. 5th Street, Suite 101, Louisville, KY $40202-4314$

Questions or additional information, contact: (502) 574-2985 (phone) or (502) 574-5245 (fax)

Application and fee must be received no later than 30 days prior to event

Event Name:

Official name of festival or event (name used to advertise event)

Event Producer: Name of individual, group or organization producing event, or agency with whom event is contracting

Primary Contact: Person who should be contacted regarding the application, event or in case of an emergency

Contact Address: Street Mailing Address City State Zip

Primary Contact Information:

Day Phone

Cell Phone Night Phone

Fax E-mail

Web site

Event Information:

Starting Date: 1 Time: M Ending Date: Time: M

Total attendence expected: Rain plan:

$\neg$ Block Party - \$15 $\square$ Parade - \$10 $\square$ Walk/Run/Race - \$10

$\square$ Other - $\$ 15$

Describe special features of the event:

STREET CLOSINGS - List streets to be closed for Special Event

If a state road will be closed, apply for a Street Closing Permit from the Kentucky Transportation Cabinet (See Contact List, Section 24, Special Events Handbook)

Street Closings to begin on: Date: Time: M Re-opening on: Date: M

NOTE: Louisville Metro will notify TARC if bus or trolley re-routing is going to be necessary. Attach map of the event area showing street closings and event features Event Producers must notify affected businesses and residents of street closures.

Event Producers must provide barricades for street Closings. Check Yellow Pages under "Barricades."

\section{HOLD HARMLESS AND INDEMNIFICATION CLAUSE}

The Applicant/Event Producer shall indemnify, hold harmless and defend Louisville Metro Government and the Waterfront Development Corporation (if event is held on Waterfront Park Venues), their elected and appointed officials, employees, agents and successors in interest from all claims, damages, losses and expenses including attorneys' fees, arising out of or resulting, directly or indirectly, from the Applicant/Event Producer's (or Applicant/Event Producer's subcontractors, if any) performance or breach of the contract provided that such claim, damage, loss, or expense is: (1) attributable to personal injury, bodily injury, sickness, death, or to injury to or destruction of property, including the loss of use resulting therefrom, or breach of contract, and (2) not caused by the negligent act or omission or willful misconduct of Louisville Metro Government or the Waterfront Development Corporation, their elected and appointed officials and employees acting within the scope of their employment. This Hold Harmless and Indemnification Clause shall in no way be limited by any financial responsibility or insurance requirements and shall survive the termination of this Small Event Permit Application.

Only applicants in good standing with Louisville Metro will be considered for approval. Any misrepresentation in this application or deviation from the final approved specifications and activities described herein or failure to abide by all Federal, State and Louisville Metro laws, ordinances, policies and procedures may result in the immediate revocation of the approved permit and/or refusal to issue a permit in the future.

$X$ Signature of the agent duly authorized by the Special Event Permit applicant to bind it.

Date:

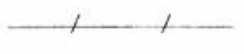




\title{
Appendix C
}

\section{Sample Service Plans}

\author{
C-1 JTA Jacksonville Super Bowl XXXIX \\ C-2 VOTRAN Pepsi 400 Winston Cup Series Race \\ C-3 LYNX Florida Classic \\ C-4 CTA Taste of Chicago
}


Appendix C-1

JTA Jacksonville Super BowI XXXIX Service Plan 


\section{Jacksonville Super Bowl XXXIX \\ Executive Summary \\ Jacksonville Transportation Authority}

Tom Jury

Updated December 9, 2004 


\section{Jacksonville Super Bowl XXXIX \\ Executive Summary}

The Jacksonville Transportation Authority (JTA) will provide professional transportation services in support of NFL Super Bowl XXXIX scheduled for Sunday, February 6, 2005 in Jacksonville, Florida.

The JTA has developed a Super Bowl Transportation Plan during the last several months. Fact-finding trips were made to Daytona, Florida during the 2003 Daytona 500 race and Houston, Texas during Super Bowl XXXVIII to review transportation models used during similar major events. The Authority has also remained active attending ongoing planning meetings with the Jacksonville NFL Host Committee and conducting bi-weekly internal Super Bowl planning meetings.

A JTA Super Bowl procedure manual and power point presentation has been developed as a road map to ensure that each component of the transportation plan is organized and carried out to completion on schedule. The manual is comprehensive and defines each of JTA's internal Department's Super Bowl responsibilities. A project scheduling Gantt chart will remain in use until game day for project organization and timeline compliance.

The transportation services JTA will provide for the Super Bowl game are similar to the services provided since 1995 in support of the Jaguars Stadium Shuttle Service. A primary difference is the Shipyard Transportation Hub selected to replace the existing stadium drive-up ramp and shuttle lots located adjacent to the stadium. An alternative Shipyard Transportation Hub, located within walking distance of the stadium, will be used. On Super Bowl Sunday, 250 buses are scheduled to meet the demand created by additional patrons expected to use JTA's bus services to and from the game.

Regular daily bus service will continue during Super Bowl week. While several detours can be expected, daily bus service will continue to operate on-schedule. To accommodate increased Superfest and NFL Experience transportation demand, 40 additional buses with operators will be leased for use beginning February 3, 2005 through a private carrier supplementing JTA's existing bus fleet.

An important component of the JTA Super Bowl Transportation Plan is the use of Duval Street as a dedicated bus route. This provision will ensure uninterrupted transportation access during all Super Bowl events. Buses will circulate non-stop from the Convention Center Station Park-and-Ride location to the Shipyard Transportation Hub and Kings Avenue Station. Additionally, bus and emergency vehicle traffic will have priority along one lane on the Acosta Bridge. 


\section{Superfest}

Beginning on Thursday, February 3, 2005 is Superfest; located along Bay Street from the Landing east to the Shipyard. Patrons will have the choice of using JTA bus or Skyway transportation from Convention Center Station on the north bank of the Saint Johns River and Kings Avenue Station located on the south bank. Bus transportation service from three (3) new Park-and-Ride locations will also be provided to and from the Superfest location.

\section{NFL Experience}

The NFL Experience will open the weekend before the Super Bowl, January $29^{\text {th }}$ and $30^{\text {th }}$ and again starting Thursday, February 3, 2005; located along Prudential Drive. JTA's transportation services to the NFL Experience will terminate at Kings Avenue Station; located a short walking distance from the NFL Experience location. JTA bus and Skyway transportation services will be provided to Kings Avenue Station from Convention Center Station. JTA bus transportation service from three (3) new Park-and-Ride locations will also be provided to and from the NFL Experience location.

\section{Super Bowl Sunday}

JTA will provide bus transportation service to and from the Super Bowl game.

Transportation loading locations will be at the three new Park-and-Ride lots as well as existing park-and-ride locations listed (I95 North, I95 South, I10 West, Beaches, JTB, Convention Center station and Kings Avenue Station). JTA bus transportation services to the game will terminate at the Shipyard Transportation Hub located in close proximity to the stadium. JTA bus transportation service from the game will load at easily identifiable return locations within the Shipyard Hub. A continuous string of 250 buses are scheduled to return patrons to Park-and-Ride locations after the game.

\section{Park-and-Ride locations}

JTA is planning to do its part by providing convenient Park-and-Ride locations outside of the central business district. In preparation for large crowds associated with major events, three additional Park-and-Ride lots located along Interstate 95 South, Interstate 95 North and Interstate 10 West have been reserved in anticipation of increased parking demand. Electronic variable message and way-finder signs will be located along the Interstates and roads leading to the parking locations. Ongoing JTA news media releases will encourage the use of Park-and-Ride locations to reduce traffic congestion in-town. On Super Bowl Sunday, the existing Park-and-Ride locations already used during Jaguars Stadium Shuttle Service on game days will supplement the three new lots.

\section{Parking}

JTA Park-and-Ride lots will be managed by Central Parking. Central Parking responsibilities will include parking fee collection and lot supervision. Parking will be provided on a daily basis. Overnight parking will not be provided. Parking will be provided at $\$ 5$ per vehicle Thursday through Saturday. The parking fee will increase to $\$ 20$ on Super Bowl Sunday. 


\section{Transportation Pass}

JTA Super Bowl transportation services will include bus and Skyway transportation services. A $\$ 5$ daily transportation pass will provide unlimited access to bus and skyway transportation modes. A $\$ 20$ four-day transportation pass will also be available. A private water taxi service will be available and paid separately. Transportation passes will be available for sale at JTA Park-and-Ride locations.

\section{Security}

Enhanced security will be provided throughout the JTA during Super Bowl week. Each Park-and-Ride location, the parking garage and Skyway Stations will have security personnel present. Entry onto the Skyway platforms will be controlled in compliance with capacity requirements. Security will be trained in suspicious package detection and vehicle inspection techniques. Our goal is to have 92 security personnel available.

\section{Volunteers}

A corps of Super Bowl and JTA volunteers will be available to assist patrons using JTA's bus and Skyway systems. The volunteers will have special customer service training in preparation for greeting the thousands of patrons who will be visiting Jacksonville for their first time. Our goal is to have 600 volunteers available. The volunteer program is coordinated through the JTA External Communication Department and the Super Bowl Host Committee.

\section{External Communications}

External Communications will be responsible for all JTA communications during Super Bowl week. Transportation maps, brochures and other hand-outs will be provided by External Communications for the volunteers to disperse. On an ongoing basis, External Communications will communicate the availability of transportation services via radio, television and newspaper. Patrons will be encouraged to park at the JTA Park-and-Ride locations along the Interstates to prevent traffic congestion in-town. External Communication is also coordinating bus and Skyway advertising opportunities.

The Mass Transit Division is in the process of finalizing purchasing requests for buses, manpower and materials associated with the Super Bowl. Consultants from Eastern entertainment and RS\&H are performing statistical analysis relative to crowd control measures and bus/traffic sequencing.

The final goal is for JTA transportation services to be provided safely, reliably and ontime during Super Bowl week. There is work left to be done and we are on schedule. The entire JTA Super Bowl Committee is dedicated to excellence and remains excited about bringing this project to completion- second to none.

$\mathrm{TJ} / \mathrm{jd}$ 


\section{Appendix C-2 \\ VOTRAN Pepsi 400 Winston Cup Series Race Service Plan}




\section{VOTRAN \\ OPERATIONS \\ DEPARTMENT}
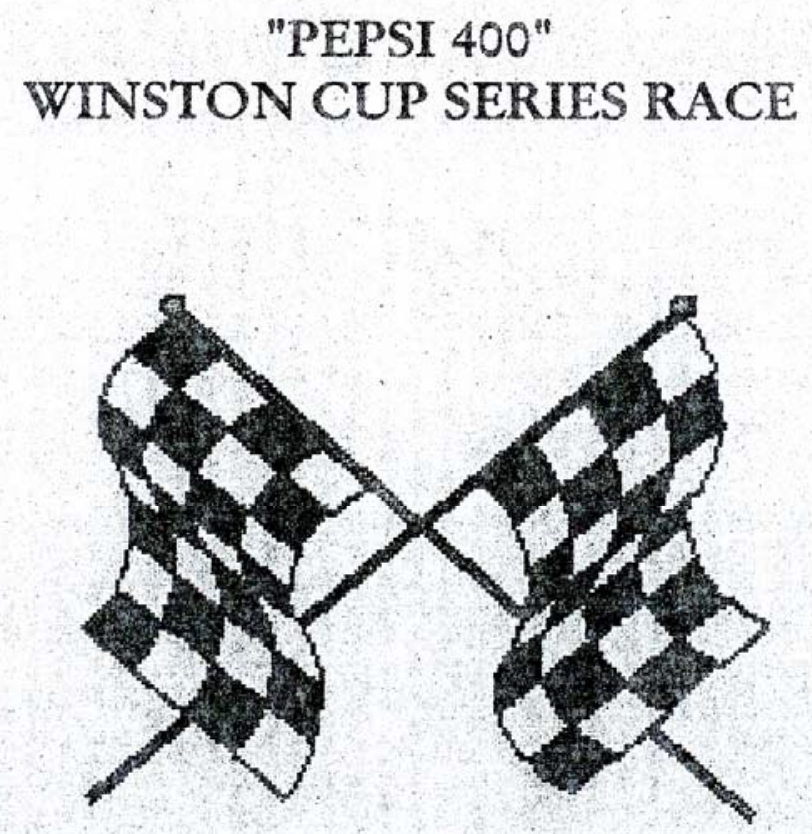

JULY 3, 1999

SHUTTLE OPERATING PLAN 


\section{VOTRAN \\ 1999 SPEEDWAY "PEPSI 400" RACE \\ OPERATING PLAN}

There is a continuing demand for additionai shuttle service to alleviate parking and traffic congestion problems in the vicinity of the Speedway. This increase in patronage will continue for several years with the additional construction of grandstands and suites planned for race fans.

For the 1999 "Pepsi 400" race VOTRAN staff is responsible for planning, coordinating and implementing six (6) separate shuttle movements for the "Pepsi 400 " race to be held on Saturday, July 3,1999 . With the fourth of July holiday falling on Sunday, VOTRAN will operate a holiday schedule on Saturday to have more vehicles and manpower available for the park and ride operations and VOTRAN Fixed Route service. Blending of Lynx, School Board and Paratransit resources will be used to meet the park and ride demand for this event. Another unique factor is operating the service for a night race.

In addition, trolley service will be enhanced to accommodate a new venue on Main Street. The Main Street Merchants Association will sponsor a street festival on Thursday, Friday and Saturday, prior to the race. To accommodate this event, the regular trolley service hours will be extended on Thursday, Friday and Saturday with two additional trolleys added on Saturday to accommodate fans attending the festival prior to the race. The regular trolley service on Thursday, Friday and Saturday will operate additional hours beginning at 9:00 a.m. and running until 12:25 a.m.. On Saturday, Four trolleys will operate from 9:10 a.m. until approximately 10:00.

VOTRAN will operate the "Speedway Special" on A1A, with a north route from US\# 92 to Granada Blvd and a south route from US $\# 92$ to Dunlawton and US $\# 1$. After loading, Buses will proceed to Martin-Marietta using Dunn Ave. through Palm Terrace School into the rear of the Martin Marietta Complex. Passengers will be dropped off in the rear parking lot of Building 5 at the designated bus parking area. The buses will be staged at that location for the return trip. The shuttles will begin service at 4:00 p.m. operating with 12 VOTRAN buses for the pre-race trip and 14 buses will be used for the return trips. Buses may need to make double trips depending on passenger loads. Round trip fare is $\$ 6.00$ per person.

The "Sunshine Park" Express Park and Ride service will be operated by the Volusia County School Board Transportation under a contract with VOTRAN. Six full size air conditioned school buses will transport passengers from Sunshine Park to Martin Marietta, via Dunn Avenue through Palm Terrace Elementary School and proceed to the designated de-boarding area at First Data Corp., Building five (5). Buses may need to double trip depending on passenger loads.

Round trip fare is $\$ 6.00$ per person. 
The "Ocean Center" Park and Ride service will be operated with six (6) VOTRAN buses. Passengers will be boarded from the west Ocean Center paved parking lot on Wild Olive Ave. and the north unpaved lot on Earl Street. The shuttles will begin operating at 4:00 p.m. Buses will proceed on a route using the Main Street Bridge to Dunn Avenue through Palm Terrace School into the rear of the Martin Marietta Complex. Passengers will de-board in the east parking lot at Building 6 . Buses will be staged there during the race.

The "DBCC Shuttle" will operate as an express bus service between Daytona Beach Community College (DBCC) and the Martin Marietta complex. Race fans will park on the northeast side of DBCC at the corner of Bethune Blvd/Welch Drive and extend south to International Speedway Blvd. Buses will travel to Martin Marietta via Dunn Ave, through Palm Terrace school grounds to the rear of the Martin Marietta complex. Passengers will de-board at First Data Corp, Building \#6. The service will be operated through a cooperative agreement with Volusia County School Board to provide 22 buses and drivers for the operation. There is no cost to use the shuttle service. Shuttle service will begin at 8:00 a.m. with two school buses. 10 buses will be added at 3:00 p.m. and an additional 10 buses will begin service at 4:30 p.m..

The backstretch operation, referred to as the "Williamson Shuttle" will serve two general parking areas which includes High Banks and the Speedway Campground formerly known as Becks. Fans will be picked up at these locations and dropped off at the Midway Transit Plaza (Gate 60) off Midway Blvd. This free shuttle service will begin with four (4) small VOTRAN buses at 8:00 a.m. with four (4) additional small buses added at 10:00 a.m. and five (5) large buses added at 12:00 noon. The VOTRAN buses will circulate between the park and ride boarding areas and the de-boarding area at gate 60 .

Beginning at 3:00 p.m., thirtyfive (35) Lynx buses will begin pre-race shuttles from the boarding areas to the de-boarding area. At 9:00 p.m. five (5) VOTRAN buses will be added to the Williamson operation to make a total of 40 buses for the post race shuitles. There will be no charge to fans for parking or for use of the shuttle service.

VOTRAN will operate the "Hospitallity Village" shuttle using 10 small buses. The shuttle will accommodate fans for the pre-race only beginning at 3:00 p.m. and will end prior to the start of the race at approximately 7:30 p.m.. This service had been established by the Speedway to accommodate guests invited to the hospitality area on the Super Backstretch. At the end of the shuttle movement at approximately 7:30 p.m., all units will assemble on the backstretch in order to exit together with the police escort.

A separate detailed plan for each shuttle movement is included as part of this plan.

$\mathrm{YC}$

$6 / 99$ 


\title{
"SPEEDWAY SPECIAL" \\ BEACHSIDE PARK \& RIDE
}

\author{
JULY 3, 1999 \\ SHUTTLE OPERATING PLAN
}




\section{SPEEDWAY SPECIAL OPERATING PLAN}

1. There are 8 trips scheduled, to provide special service to the "PEPSI 400" from A1A and U.S. 1 with 4 trips on the NORTH ROUTE and 4 trips on the SOUTH ROUTE.

a.) 12 buses will be used for this plan. (two additionai buses will be added for the return trip.)

b.) 4 buses are scheduled on each route.

c.) Additional buses will be assigned to accommodate passenger volume.

d.) All buses will make at least one trip each, addition trips will be made as passenger volume demands.

2. Staff control personnel will monitor passenger activity and co-ordinate the implementation of additional trips with dispatch.

a.) It is essential that operators follow all outlined instructions/procedures, and stand-by for explicit instructions.

3. In order to effectively monitor the status of all buses in the movement, ROUTES will be coded as North(blue) and South(red), each unit will be identified by its' designated specific block assignment. These code designations will be used instead of unit numbers when calling or being called on the radio. This will allow dispatch to more easily track each assigned unit.

4. All operators are required to notify dispatch whenever coaches are completely full with standees up to the line, using the following procedures:

a.) Report exact location/approximate number of pax.

b.) Reserve units will be placed in service to continue route, as needed.

5. En route to Speedway, buses will encounter heavy traffic on major roadways \& intersections.

a.) Contact dispatch when you reach a slowdown situation, reporting exact location/progress status.

b.) Upon arrival at staging area, the rear of Building \#5 at Martin-Marietta, follow instructions of VOTRAN staff.

c.) Some units will be required to make at least one additional trip.

c.) After final inbound trips buses will be staged in the parking area of Building 5 , Martin-Marietta until the race is over.

d.) Supervisor will give specific instructions at staging area. 


\section{SPEEDWAY SPECIAL FARE PROCEDCRES}

1. Operators will make change, if absolutely necessary. Each driver will be given a particular amount of starting change.

2. Fare is $\$ 6.00$ per person. No reduced fares, passes or employee I.D. cards will be honored.

3. Passengers pay for round trip. Issue one "Token" for each round trip fare paid.

a.) In addition, please inform them that they must present "Token" for return trip.

NOTE: Be sure you have pouch with any money and any "Token" cards in your possession at all times. Do not leave it unattended, on bus.

4. DO NOT USE KNEELERS! (when filled to capacity, a kneeled bus may not move)

5. All operators will fill out a "Passenger Count" form and turn in at deboarding zone after final in-bound trip.

6. Do not issue "Token" cards for one-way trip payment. These passengers must pay an additional $\$ 3.00$ when re-boarding on return trip.

7. On return trip, passengers with no "Token" pay \$3.00. Passengers presenting

"Token" cards do not pay.

8. Fareboxes will not be used. Each operator will be issued a pouch, for money collected. After your final in-bound trip a staff person will collect pouch when you are parked at the Speedway, in addition completed "Passenger Count" sheets will be turned in at this time.

9. On return trip after race, hold any money collected and turn it in at roll-in with your special movement paperwork.

10. On return trip after race buses will be identified by color:

BLUE: NORTH
RED: SOUTH
YELLOW: SUNSHINE PARK
GREEN: OCEAN CENTER

Each bus will be identified by a dash sign in the same color as the return trip token issued to passengers.

11. When arriving at Martin-Marietta, do not advise passengers to re-board your particular bus! Remind them as they deboard, to look for a bus with the same color dash sign for their return trip.

12. Do not open doors. until instructed by staff.

njw disk: PEPSI400 file:400,pro 


\section{SPEEDWAY SPECIAL ROUTING/STAGING}

Left on Big Tree Rd.

Left on S. Ridgewood Ave. (U.S. 1)

Right on I.S.B. (U.S. 92) to s. Atlantic Ave. (A1A)

\section{NORTH ROUTING}

Starts at S. Atlantic Ave. (A1A) \& I.S.B. (U.S. 92)

Left on Atlantic Ave. (AlA)

Left on Granada Blvd. (S.R. 40)

Left on S. Yonge St. (U.S.1)

Right on Fairview Ave. (George Engram Bivd) (Dunn Ave.)

L.eft into the first entrance gate to Palm Terrace Elementary School

Continue South through the paved parking lot and unpaved school yard.

Exit the school yard gate onto Industrial Blvd.

Left at the second building entrance (Speedway Office Building $\# 5$ )

Deboard passengers and stage on the East side of Building $\# 5$

NOTE: Speedway Specia! buses will be making at least two tirps. Make your turn-around in the parking lot of building \#5, exit to your right onto Industrial Blvd. and back across the school property to Dunn Ave. East on Dunn Ave, to U.S. 1 South on U.S. 1 to I.S.B. and East across the bridge to Al A where you will start boarding. You may also be directed North on Peninsula Drive to points North on AlA that need servicing. Passeners should be picked up at regular Bus Stops on East side of A1A. North side of Granada Blvd. and the West side of U.S. 1.

\section{SOUTH ROUTING}

Starts at S. Atiantic Ave. (A1A) and I.S.B. (U.S. 92)

Right on S. Atlantic Ave. (AlA)

Right on dunlawton Blvd. (S.R. 421)

Right on S. Ridgewood Ave. (U.S. 1)

Left on Fairview Ave. (George Engram Blvd.) (Dunn Ave.)

Left into the first entrance gate to Palm Terrace Elementary School

Continue South through the paved parking lot and unpaved school yard.

Exit the school yard gate onto Industrial Blvd. (Paved Roadway)

Left into the second building entrance. (Speedway Office Building 5)

Deboard passengers and stage on the East side of Building \#5

NOTE: Speedway Special buses will be making at least two tirps. Make your turn-around in the parking lot of building \#5, exit to your right onto Industrial Blvd. and back across the school property to Dunn Ave. East on Dunn Ave. to U.S. I South on U.S. 1 to I.S.B. and East across the bridge to A1A where you will start boarding. You may also be directed South on Peninsula Drive to points South on AlA that need servicing. Passeners should be picked up at regular Bus Stops on West side of AlA, North side of Dunlawton Blvd. and East side of U.S. 1.

njw disk: pepsi400 file:ssroute.pro 


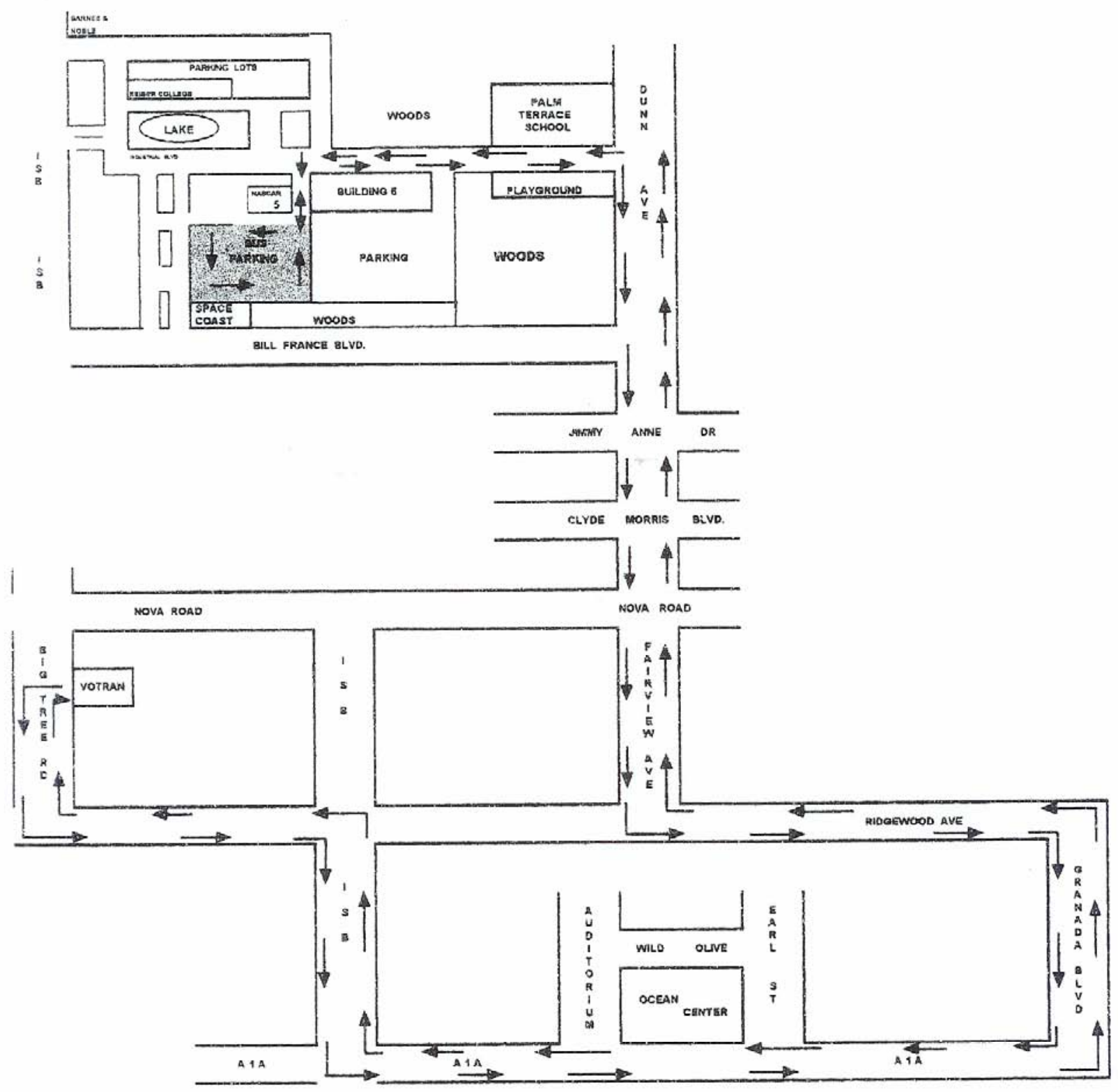

1) CALL DISPATCH AS SOON AS BUS BECOMES FULL FOR INSTRUCTIONS

2) CALL DISPATCH AFTER LAST PASSENGER HAS DEBOARDED FOR INSTRUCTIONS 


\section{BEACHSIDE PARK \& RIDE - SOUTH ROUTE}

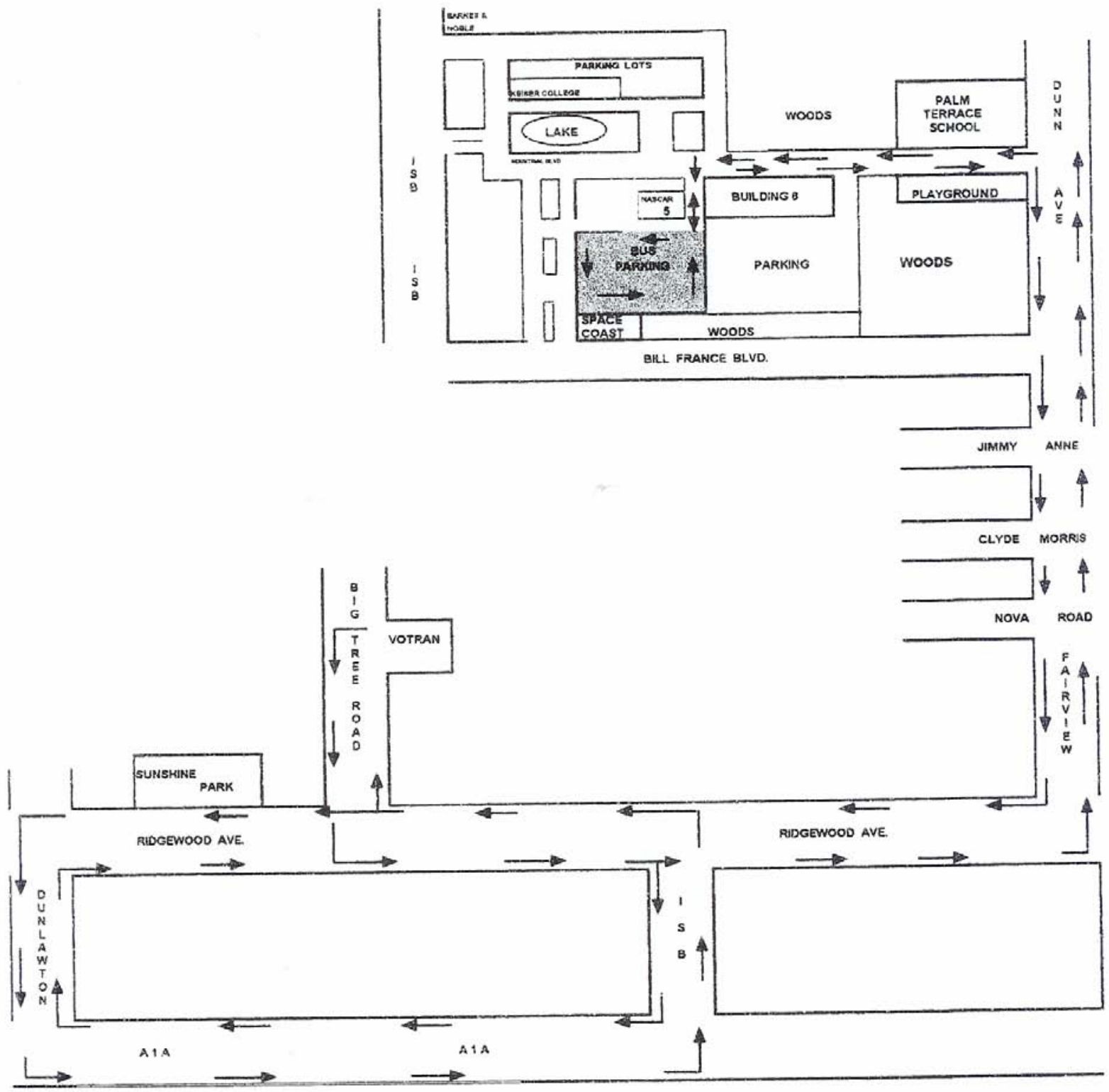

1) AS SOON AS THE BUS BECOMES FULL, CALL DISPATCH FOR INSTRUCTIONS

2) AFTER THE RACE, CALL DISPATCH FOR INSTRUCTIONS WHEN THE LAST PASSENGER HAS DEBOARDED

$06 / 1129909040098$ c: $\operatorname{lot} 50$ 


\section{Passenger Count}

LOG YOUR PASSENGER COUNTS FOR ORIGINATING TRIPS ONLY - DO NOT COUNT PASSENGERS ON RETURN TRIPS.

Operator Name

Bus Number Date

Seating capacity of this vehicle

Please place an $X$ under the column that best describes your passenger count.

Full --- equals passengers standing to white line.

$3 / 4$ Full -- equals all seats full some passengers standing.

$1 / 2$ Full -.- equals most seats full no one standing.

$1 / 4$ full -. equals more than haif the seats are empty.

Trip 1

Trip \# 2

Trip \# 3

Trip \# 4

Trip \#5

Trip 6

Trip 7

Trip \#8

Trip 9

Trip 10

Trip 11

Trip \# 12

Trip 13

Trip \# 14

Trip $\$ 5$

Trip \# 16

Trip \# 17

Trip \# 18

Trip \# 19

Trip \# 20

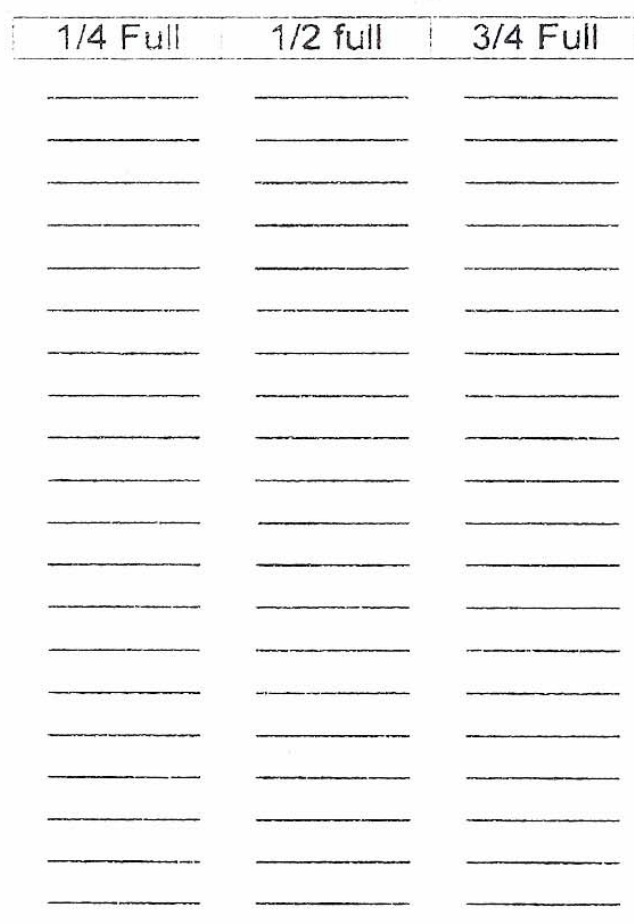

06/17/99 disk: 500 file: paxcount.wk4 niw 
Appendix C-3

LYNX Florida Classic Service Plan 


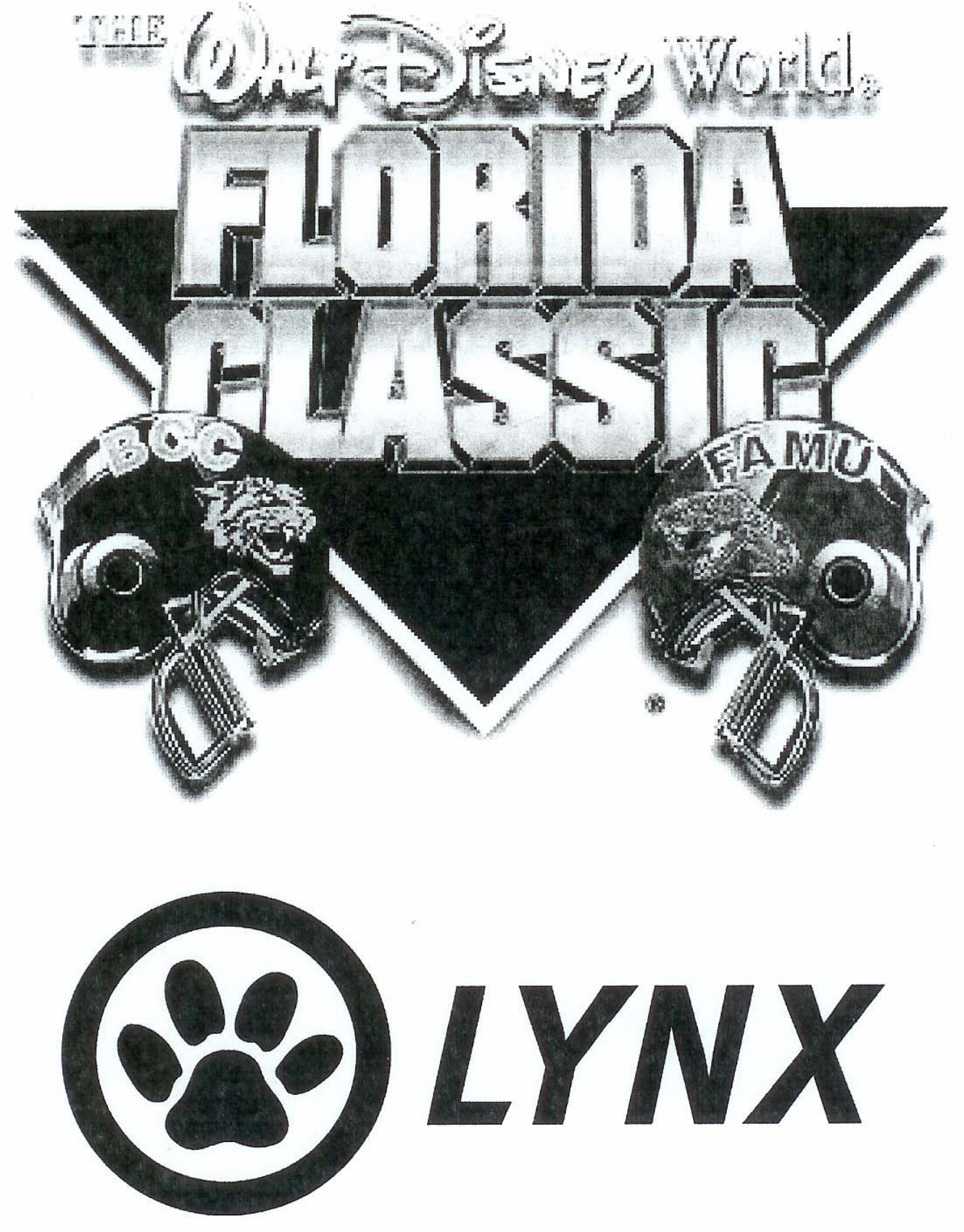

OPERATIONS PLAN

SATURDAY, NOVEMBER 19, 2005 
Page 1 - Bethune-Cookman Wildeat vs. Florida A \& M Rattlers Shuttle Operations Plan 2005

\section{INTRODUCTION}

LYNX will be providing SHUTTLE SERVICE for the Florida Classic XXVI Football Game BethuneCookman Wildcat vs. Florida A \& M Rattlers and Concert after the game. This event will be held at the Citrus Bowl on Saturday, November 19, 2005. LYNX will operate shuttle service from the old Downtown Bus Station (DBS) at Central Boulevard. The regular shuttle service for riding customers will be FREE OF CHARGE. The employee shuttle will begin at 9:00 AM and the REGULAR SHUTTLE will begin at 12:00 p.m. with six (6) buses from DBS. At 2:00 PM six (6) additional buses will report to DBS for the pre-game shuttle operations.

The gates of the Citrus Bowl open at 1:30 p.m. and the game is scheduled to begin at 3:30 p.m. LYNX will continue to provide shuttle service until approximately 12:00 Midnight.

For the post event, twelve (12) buses will report to Downtown Bus Station (DBS) at Central Boulevard, no later than 5:00 p.m. Six (6) of the twelve (12) buses will be used for the post concert event.

\section{DOWNTOWN BUS STATION (DBS) AT CENTRAL BOULEVARD SHUTTLE REOUIREMENTS}

Pre-Game Requirements: $\quad$ Two (2) buses (At Downtown Bus Station - DBS) by 9:00 AM, Operators report to South Street at 8:30 AM.

Four (4) buses (At Downtown Bus Station - DBS) by 10:00 AM, Operators report to South Street at 9:30 AM.

Six (6) buses (At Downtown Bus Station - DBS) by 12:00 PM, Operators report to South Street at 11:30 AM.

Six (6) buses (At Downtown Bus Station - DBS) by 2:00 PM, Operators report to South Street at 1:30 PM.

Post-Game Requirements: Twelve (12) buses (At Downtown Bus Station - DBS) by 5:00 PM), Operators report to South Street at 4:30 PM.

Total of thirty (30) buses.

\section{DEADHEAD ROUTE FROM SOUTH STREET FACILITY TO THE DOWNTOWN BUS STATION AT CENTRAL}

Depart South Street Facility: (R) Woods, (L) Anderson, (L) Division, (R) Central, (R) Hughey, (L) Bob Snow Lane, (L) Garland, (R) Pine St.*, (L) into Downtown Bus Station at Central. *Supervisor will provide direction. 
Pàge 2 - Bethune-Cookman Wildcat vs. Florida A \& M Rattlers Shuttle Operations Plan 2005

\section{ROUTING TO THE CITRUS BOWL FROM THE DOWNTOWN BUS STATION AT CENTRAL}

Depart DBS: (L) Central, (L) Nashville. The drop off point is located near the corner of Nashville and Church. Please drop off at the sidewalk provided for boarding/alighting. DO NOT DROP OFF PASSENGERS PRIOR TO YOUR ARRIVAL AT NASHVILLE AND CHURCH.

\section{ROUTING BACK TO THE DOWNTOWN BUS STATION AT CENTRAL FROM NASHVILLE AND CHURCH}

Depart Nashville: (L) Church, (L) Garland, (R) Pine, *(L) Into the Downtown Bus Station. *Supervisor will provide direction.

\section{DESTINATION SIGNS TO BE DISPLAYED}

The overhead destination sign is to read Citrus Bowl on all trips to and from the game.

\section{ASSIGNMENT OF BLOCK NUMBERS}

Each bus will be assigned a special Block Number. Block 60-1 through Block 60-30 (regular shuttle) will be used for the Shuttle buses. These Block Numbers will be assigned to both pre-game and post-game buses. Always refer to your Block Number when calling Dispatch and on your paper work. Please remember to state your Block number, Location, and Direction.

\section{SUPERVISION AND STAFF INFORMATION}

Transportation Supervisors will be assigned to the Downtown Bus Station (DBS) and Nashville Site. Supervisor assignments will be published under a separate cover and issued prior to the game. Some Supervisors working this event will require the following equipment:

- Flashlight and batteries

- Reflective vest

- $\quad$ Portable Radio with spare battery

Please remind all Operators to complete the "Driver Requirements" Section. Supervisors \& Staff personnel (Except T-61) are required to be at their assigned location no later than 11:50 a.m. Staff employees will assist with loading customers on to buses. However, all Transportation Supervisors will assist in bus loading when needed.

\begin{tabular}{|c|c|c|c|c|c|c|c|}
\hline \multicolumn{9}{|c|}{ TRANSPORTATION SUPERVISORS } \\
\hline T\# & UNIT & $\begin{array}{c}\text { NEXTEL } \\
\text { UNIT }\end{array}$ & $\begin{array}{c}\text { ESTIMATED } \\
\text { HOURS }\end{array}$ & $\begin{array}{c}\text { PRE-GAME } \\
\text { LOCATION }\end{array}$ & $\begin{array}{c}\text { POST-GAME } \\
\text { LOCATION }\end{array}$ & $\begin{array}{c}\text { ASSIGNED } \\
\text { SUPERVISOR }\end{array}$ & $\begin{array}{c}\text { ESTIMATED } \\
\text { WORK } \\
\text { HOURS }\end{array}$ \\
\hline T-60 & N/A & 86 & $\begin{array}{c}11: 30 A-12: 00 A \\
\text { SOUTH STREET }\end{array}$ & $\begin{array}{c}\text { Pine St. \& } \\
\text { RR Crossing }\end{array}$ & $\begin{array}{c}\text { Nashville \& } \\
\text { Church }\end{array}$ & Madelyn Barisic & 12.50 \\
\hline T-61 & $\begin{array}{c}\text { Spare } \\
\text { Vehicle }\end{array}$ & 77 & $\begin{array}{c}8: 30 A-9: 00 P \\
\text { SOUTH STREET }\end{array}$ & $\begin{array}{c}\text { Loading Area } \\
\text { @ DBS }\end{array}$ & $\begin{array}{c}\text { Nashville \& } \\
\text { Church }\end{array}$ & Samucl Pagan & 12.50 \\
\hline T-62 & 78 & 78 & $\begin{array}{c}11: 30 A-12: 00 A \\
\text { SOUTH STREET }\end{array}$ & $\begin{array}{c}\text { Nashville \& } \\
\text { Church }\end{array}$ & $\begin{array}{c}\text { Nashville \& } \\
\text { Church }\end{array}$ & Raul Adames & 12.50 \\
\hline T-63 & $\begin{array}{c}\text { Spare } \\
\text { Vehicle }\end{array}$ & Spare & $\begin{array}{c}11: 30 A-12: 00 A \\
\text { SOUTH STREET }\end{array}$ & $\begin{array}{c}\text { Loading Area } \\
\text { @ DBS }\end{array}$ & $\begin{array}{c}\text { Loading Area } \\
\text { @ DBS }\end{array}$ & Miguel Marrero & 12.50 \\
\hline
\end{tabular}


Page 3 - Bethune-Cookman Wildcat vs. Florida A \& M Rattlers Shuttle Operations Plan 2005

\begin{tabular}{|c|c|c|c|c|}
\hline \multicolumn{5}{|c|}{ STAFF } \\
\hline ESTIMATED HOURS & $\begin{array}{l}\text { PRE-GAME } \\
\text { LOCATION }\end{array}$ & $\begin{array}{l}\text { POST-GAME } \\
\text { LOCATION }\end{array}$ & $\begin{array}{l}\text { ASSIGNED STAFF } \\
\text { EMPLOYEE }\end{array}$ & $\begin{array}{c}\text { ESTIMATED WORK } \\
\text { HOURS }\end{array}$ \\
\hline $\begin{array}{c}\text { 11:30A - 9:00P } \\
\text { SOUTH STREET }\end{array}$ & DBS & Nashville \& Church & $\begin{array}{l}\text { Jessica } \\
\text { Cardona }\end{array}$ & \\
\hline $\begin{array}{c}11: 30 \mathrm{~A}-9: 00 \mathrm{P} \\
\text { SOUTH STREET }\end{array}$ & DBS & Nashville \& Church & $\begin{array}{c}\text { Olivia } \\
\text { Whitaker }\end{array}$ & - \\
\hline $\begin{array}{c}\text { 1:30P - 10:00P } \\
\text { SOUTH STREET }\end{array}$ & DBS & Nashville \& Church & $\begin{array}{c}\text { Janell } \\
\text { Thomas }\end{array}$ & \\
\hline $\begin{array}{c}\text { 1:30P - 12:00A } \\
\text { SOUTH STREET }\end{array}$ & DBS & Nashville \& Church & & \\
\hline & & & TOTALS & 38.00 \\
\hline
\end{tabular}

Bold-Confirmed to work.

\section{DISPATCHER RESPONSIBILITIES AND GENERAL INFORMATION}

All work will be assigned in accordance with our current contract. Each bus operator must be provided a copy of the LYNX TRANSPORTATION OPERATIONS PLAN and Community Service Form. Radio Dispatch will communicate with Supervisors and Maintenance on Channel ONE (1) only. If additional buses are required, please assign Block Numbers in ascending sequence. When the shuttle bus operators return to Operations Base, check their paper work for completeness and accuracy.

\section{SAFETY CONSIDERATIONS FOR BUS OPERATORS}

When operating your bus over the listed routings, please exercise extreme caution. There is expected to be a great deal of congestion in the areas surrounding the Citrus Bowl. For your safety, your passenger's safety, and other motorists, we ask you to operate at safe speeds and check your clearances when in motion.

\section{Game Information:}

\section{PROHIBITIVE ITEMS}

For this event the following items are not permitted: backpacks, video cameras or cases, water, bottles, cans, coolers, containers, signs, poles, flags with $15 \%$ or larger sticks, umbrellas, balls, Frisbees, weapons, fireworks, drugs, alcohol, food, drinks or other items deemed inappropriate. Small mini-pack purses ok.

Security personnel have the right to inspect any items at any time.

\section{OPD SUPPORT FOR THE SHUTTLE}

Five (5) OPD officers will be required to assist LYNX with traffic control and security. The pre-event OPD officers will be on duty from 11:50 a.m. until approximately two hour after the event ends.

- One (1) OPD Officer will be assigned to Central Boulevard, at the exit of the Downtown Bus Station at Central for traffic control.

- $\quad$ One (1) OPD Officer at Central Boulevard and Orange Blossom Trail.

- $\quad$ One (1) OPD Officer will be at Nashville Avenue and Central Boulevard.

- $\quad$ One (1) OPD Officer will be at Nashville Avenue and Church Street.

- $\quad$ One (1) OPD Officer post event at Church Street and Orange Blossom Trail.

Note: The post-event OPD officers will be on duty before the end of the game (end of the third quarter). 
Page 4 - Bethune-Cookman Wildcat vs. Florida A \& M Rattlers Shuttle Operations Plan 2005

\section{TRAFFIC CONTROL SUPPORT FOR THE SHUTTLE}

Four (4) Traffic Control employees will be required to assist LYNX with traffic control. The pre-event Traffic Control employees will be on duty from 11:50 a.m. until approximately one hour after the game ends.

PLEASE PROVIDE BUSES PRIORITY THROUGH THE INTERSECTIONS BELOW

- One (1) Traffic Control employee will be assigned to the corner of Central Boulevard and Hughey Avenue.

- One (1) Traffic Control employee will be assigned to the corner of Central Boulevard and Garland Street.

- One (1) Traffic Control employee will be assigned to the corner of Church Street and Westmoreland Avenue.

- One (1) Traffic Control employee will be assigned to the comer of Central Boulevard and Westmoreland Avenue.

Note: A generator light will be required at the Nashville and Church loading area.

\section{MEALS}

LYNX will provide refreshments (Water and Soda).

\section{PASSENGER COUNT}

All Bus Operators will be required to count passengers traveling from the Downtown Bus Station at Central to Nashville and the return. Please check your packet for a passenger count sheet. In the event you have not been provided with a passenger count sheet, dispatch will provide you with one.

\section{MAINTENANCE DEPARTMENT SUPPORT}

Downtown Bus Station (DBS) at Central Boulevard and Nashville and Church will require some crowd control devices for loading and unloading passengers.

\section{SPECIAL POST-GAME INFORMATION FOR BUS OPERATORS}

When pulling your bus in to the loading site at Nashville and Church for the post-game return, DO NOT OPEN YOUR DOORS UNTIL DIRECTED TO DO SO BY A SUPERVISOR OR LOADER.

This Transportation Operations Plan is subject to change and all involved individuals will be notified of any changes to this plan. If there are any questions, please contact Rey Quiñones, Chief Supervisor (321-436-4554).
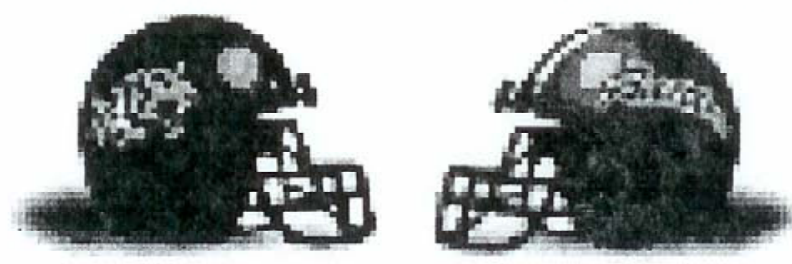


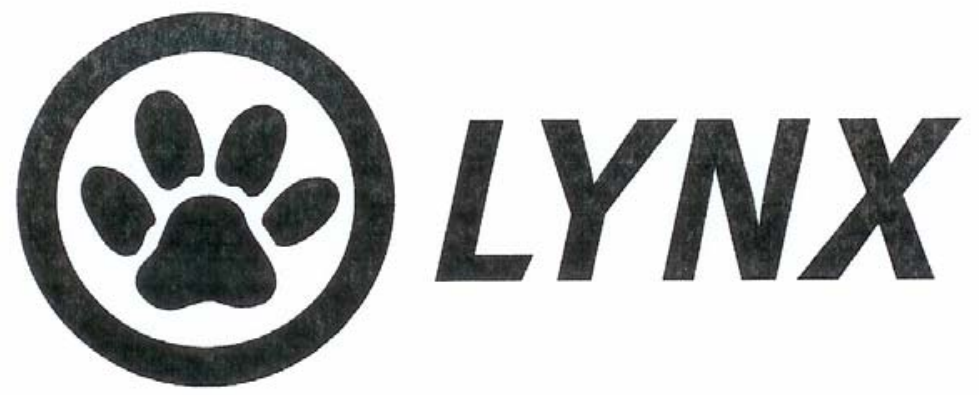

\section{Maintenance Plan for the November 19, 2005 Citrus Bowl Shuttle Florida Classic XXVI}

The Citrus Bowl Shuttle is scheduled for November 19, 2005. Listed below are the details for Maintenance support of the shuttle operation.

\section{MAINTENANCE SUPPORT}

Maintenance will provide support from OBT. There will be a service truck as well as relief buses available from OBT till the event is over.

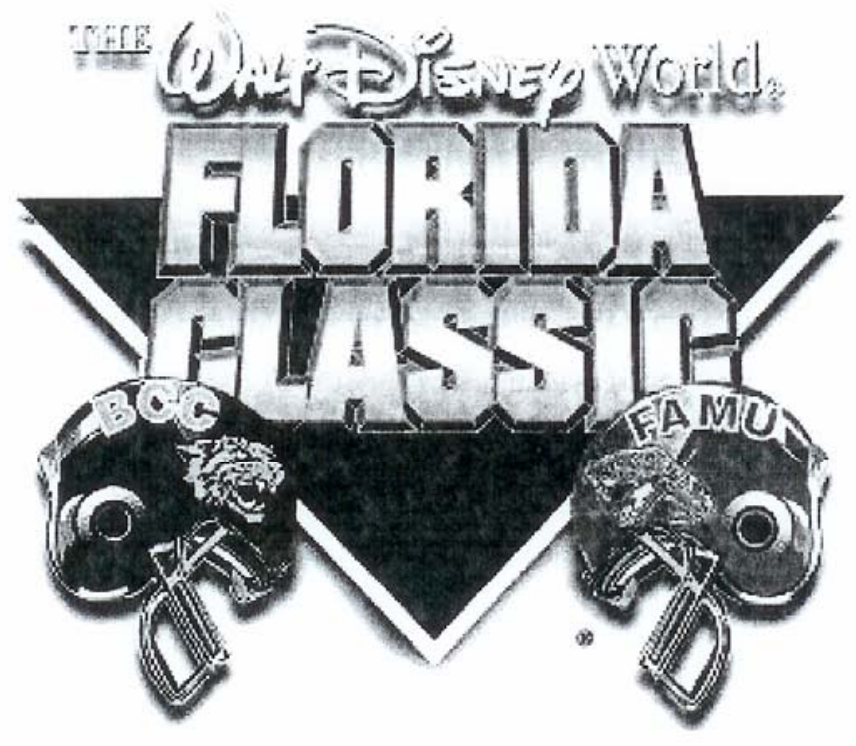


Page 6 - Bethune-Cookman Wildcat vs. Florida A \& M Rattlers Shuttle Operations Plan 2005

\begin{tabular}{|c|c|c|c|}
\hline Buse & $\begin{array}{l}\text { Sethune-Cool } \\
\text { lorida A \& } N \\
\text { signed to Sh }\end{array}$ & $\begin{array}{l}\text { Wildcat } \\
\text { tlers sht } \\
\text { - Total }\end{array}$ & 0 units \\
\hline NUMBER & BUS ASSIGNED & NUMBER & BUS ASSIGNED \\
\hline 1 & 551 & 18 & 267 \\
\hline 2 & 552 & 19 & 268 \\
\hline 3 & 381 & 20 & 269 \\
\hline 4 & 382 & 21 & 270 \\
\hline 5 & 385 & 22 & 271 \\
\hline 6 & 388 & 23 & 272 \\
\hline 7 & 391 & 24 & 273 \\
\hline 8 & 392 & 25 & 202 \\
\hline 9 & 393 & 26 & 218 \\
\hline 10 & 394 & 27 & 238 \\
\hline 11 & 260 & 28 & 418 \\
\hline 12 & 261 & 29 & 422 \\
\hline 13 & 262 & 30 & 427 \\
\hline 14 & 263 & & \\
\hline 15 & 264 & & \\
\hline 16 & 265 & & \\
\hline 17 & 266 & & \\
\hline & & & \\
\hline
\end{tabular}

Bus list Subject to Change! 
Page 7 - Bethune-Cookman Wildcat vs. Florida A \& M Rattlers Shuttle Operations Plan 2005

\section{LYNX OPERATIONS COORDINATORS}

\begin{tabular}{|l|l|l|}
\multicolumn{1}{r}{$\begin{array}{c}\text { POINT OF } \\
\text { CONTACT }\end{array}$} & \multicolumn{1}{c|}{ PHONE NUMBERS } \\
\hline Rey Quiñones & Chief Supervisor & $\begin{array}{l}\text { 321-436-4554 Cell } \\
* 158 * 41 * 973 \text { Radio }\end{array}$ \\
\hline Bill Zielonka & Industrial Safety Officer & $\begin{array}{l}321-436-4582 \text { Cell } \\
* 158 * 41 * 981 \text { Radio }\end{array}$ \\
\hline Terry Roedell & $\begin{array}{l}\text { Maintenance Supervisor } \\
\text { (South Street Division) }\end{array}$ & $\begin{array}{l}321-228-1693 \text { Cell } \\
* 160 * 42 * 49481 \text { Radio }\end{array}$ \\
\hline Truck 68 & South Street Technician & $\begin{array}{l}321-436-8820 \\
* 158 * 41 * 2161 \text { Radio }\end{array}$ \\
\hline
\end{tabular}

$11 / 18 / 2005$

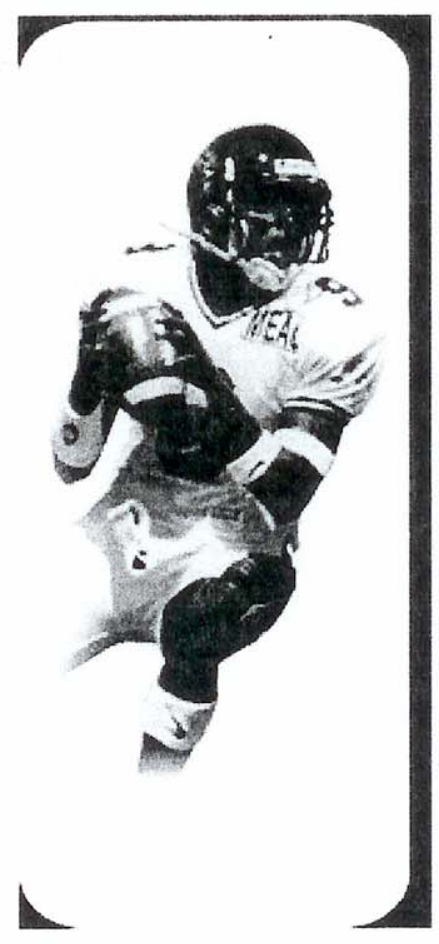




\section{(86) LYNX}

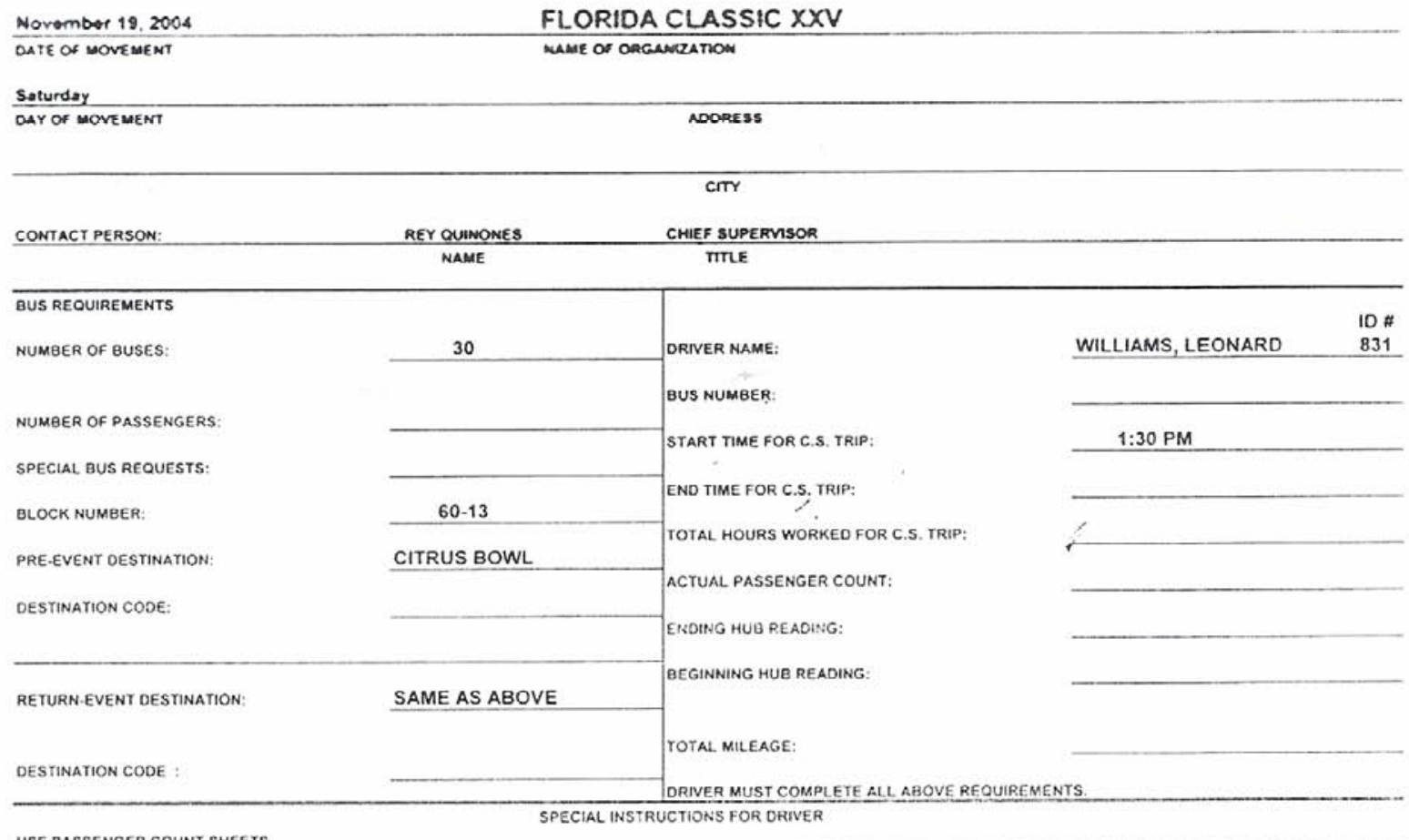

USE PASSENGER COUNT SHEETS.

REPORT TIME: 1:30 PMI ___ LEAVE GAFAGE: __ 1:45PII

PERSON TO WHOM DRIVER SHOULD REPORT: SUPERVISOR ONDUTY

EXACT LOCATION IST PICK.UP POINT: $\quad$ See Operations Plan

FIRST DESTINATION

SECOND DESTINATION:

THIRD DESTINATION:

THIRD DESTINATION

FOURTH DESTINATION

FIFTH DESTINATION

SIXTH DESTINATION

RETURN TO GARAGE:

ADOMIONAL INFORMATION

OISTRIBUTION

G TRADISPATCHDAVTCONH WKA

See Operations Plan ARRIVAL

DBS

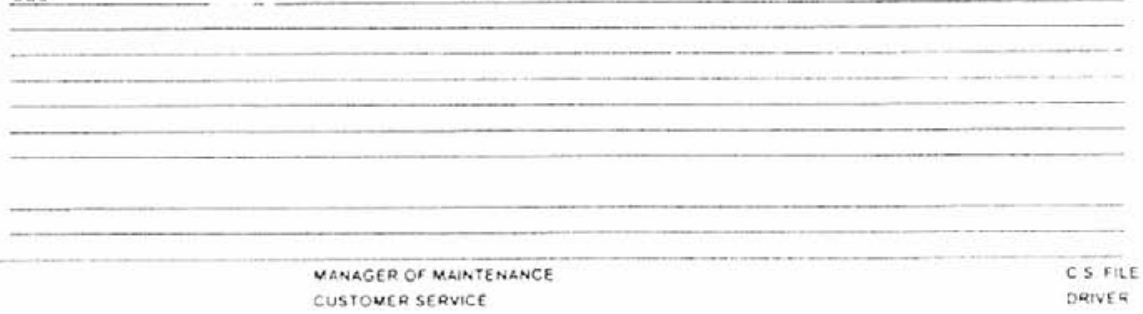




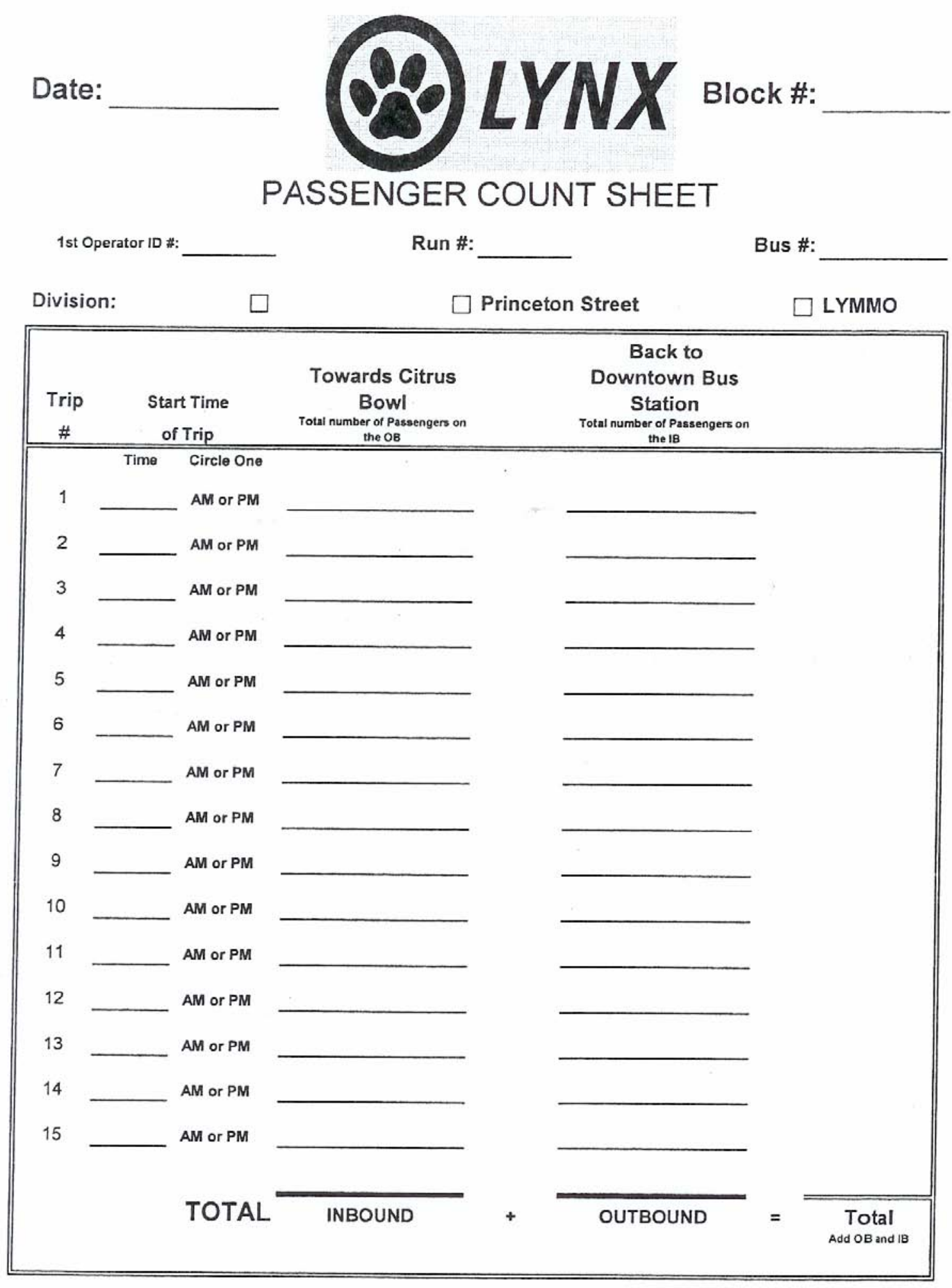

Passenger Count Sheet Citrus Bowl 
Appendix C-4

Chicago Transit Authority (CTA) Taste of Chicago Service Plan 


\section{July $3^{\text {rd }} /$ Taste of Chicago and Navy Pier Extra Bus Service 2004 CTA Bus Operations Playbook}

\section{Bus Operations Overview}

CTA Bus Operations provides extra bus service, operations management personnel, and nonoperations information specialists to serve the large crowds leaving the lakefront after the fireworks on July $3^{\text {rd }}$. All CTA employees are reminded that every ride should be counted, as this is traditionally the highest ridership day of the year.

This year, Bus Operations is providing 364 extra buses for the event. All extra buses will be staged by 1930 hours. Bus Service Management personnel will manage bus circulation, staging, and moving buses from staging areas to boarding locations during the break. Bus Operations general managers will provide customer information and manage customer boarding in their assigned coverage areas, with the assistance of their management personnel and nonoperations employees.

The following information is provided in this document:

- Extra service provided by route, garage and staging location

- Bus staging and boarding locations

- CTA Staffing: Bus Operations supervision and management and non-operations personnel

- Customer boarding locations and reroutes

- Customer information, including outbound boarding locations and maps

- Contact information for Bus Operations and other CTA personnel

The appendix includes:

- Palm card (boarding locations and reroute information)

- Lakefront Busway evacuation map

- Navy Pier flyer and circulation map

- Metra system map and last train times

- Downtown Map (bus staging, boarding, and managerial assignments)

July $3^{\text {rd }} /$ Taste of Chicago Bus Operations Playbook

Version: July 1, 2004

7/2/2004 (3:20 PM)

Page 1 
Extra Bus Allocation by Route \& Staging Location for Saturday, July 3, 2004

\begin{tabular}{|c|c|c|c|c|c|c|c|c|c|c|c|c|c|c|c|c|c|}
\hline 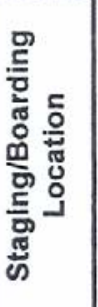 & $\frac{-1}{\frac{-}{0}}$ & 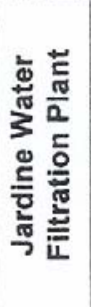 & 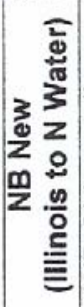 & 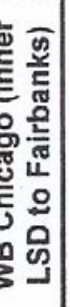 & 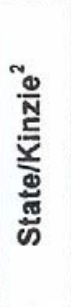 & 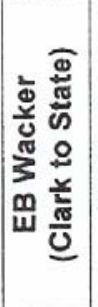 & 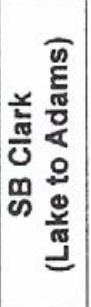 & 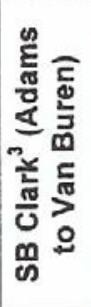 & 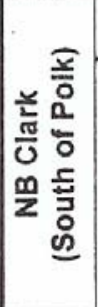 & 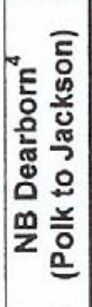 & 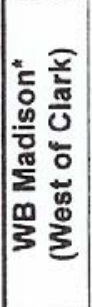 & 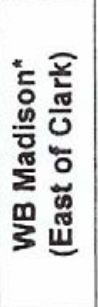 & 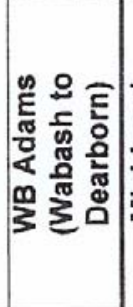 & 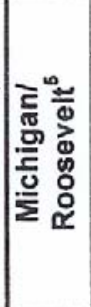 & 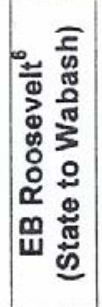 & 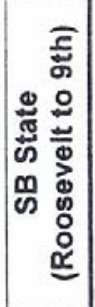 & $\begin{array}{l}\bar{\Xi} \\
\stackrel{0}{\circ}\end{array}$ \\
\hline$\# 3$ & & & & & 6 & & 5 & 2 & & & & & & & 3 & & 16 \\
\hline$\# 4$ & & & & & 8 & & 7 & 2 & & & & & & & 3 & & 20 \\
\hline \#6 & & & & & 10 & & 9 & 2 & & & & & & 4 & & & 25 \\
\hline$\# 12$ & & & & & & & & & & & & & & 14 & & & 14 \\
\hline$\# 14$ & & & & & & & 7 & 2 & & & & & & 4 & & & 13 \\
\hline \#20 & & & & & & & & & + & & & $\begin{array}{l}10 \\
10\end{array}$ & & & & & 20 \\
\hline$\# 22$ & & & & & & & & & $\begin{array}{l}6 \\
3 \\
\end{array}$ & 5 & & & & & & & 14 \\
\hline \#29 & 11 & & 10 & & 4 & & 3 & 2 & & & & & & & & 5 & 35 \\
\hline$\# 36$ & & & & & & & & & 4 & 7 & & & & & & & 11 \\
\hline$\# 56$ & & & & & & & & & & & & 15 & & & & & 15 \\
\hline$\# 60$ & & & & & & & & & & & 25 & & & & & & 25 \\
\hline$\# 62$ & & & & & 11 & & & 2 & & & & & & & & 7 & 20 \\
\hline$\# 65$ & 10 & $\begin{array}{r}8 \\
11\end{array}$ & & & & & & & & & & & & & & & 29 \\
\hline$\# 66$ & 12 & 17 & & & & & & & & & & & & & & & 29 \\
\hline$\# 124$ & 6 & 9 & & & & & & & & & & & & & & & 19 \\
\hline$\# 126$ & & & & & & & & & & & & & $\begin{array}{c}11 \\
7\end{array}$ & & & & 18 \\
\hline$\# 146$ & & & & & & & & & 7 & 5 & & & & & & & 12 \\
\hline$\# 147$ & & & & & & 2 & & & 1 & 5 & & & & & & & 8 \\
\hline$\# 151$ & & & & 3 & & 5 & & & 7 & 6 & & & & & & & 21 \\
\hline Total & 39 & 45 & 10 & 3 & 39 & 7 & 31 & 12 & 28 & 28 & 25 & 35 & 18 & 22 & 6 & 12 & 364 \\
\hline
\end{tabular}

Articulated buses are in bold. Foreign garage operations are in italics.

${ }^{1} \# 65$ and \#66 - In CTA terminal. \#124 - WB Grand (West of Streeter). Four \#124 Navy Pier buses will be in circulation at the break. \#29-NB in front of Navy Pier.

${ }^{2}$ Staging Locations: SB State (South of Kinzie). EB Kinzie (Dearborn to State). NB Dearborn (Wacker to Kinzie).

${ }^{3}$ Boarding Locations: \#3, \#4 - Van Buren. \#6, \#14 - Jackson. \#29, \#62 - Adams.

${ }^{4}$ Boarding Locations: \#22, \#36 - Adams. \#146, \#147, \#151 - Jackson.

${ }^{5}$ Boarding Locations: \#6 and \#14 - EB Roosevelt FS Michigan. \#12 - WB Roosevelt FS Michigan.

Bus Staging: \#6 and \#14 - NB Michigan (Roosevelt to $14^{\mathrm{th}}$ ). \#12 - SB Michigan (Roosevelt to $9^{\text {th }}$ ).

${ }^{5}$ Boarding Locations: \#3 - EB Roosevelt NS Indiana. \#4 - SB Michigan FS Roosevelt.

"Buses will stage in the 2 northern lanes.

July $3^{\text {rd }} /$ Taste of Chicago Bus Operations Playbook 7/2/2004 (3:20 PM) 
Extra Bus Allocation by Route \& Garage for Saturday, July 3, 2004

The following extra service will be provided on July $3^{\text {rd }}$ as follows:

\begin{tabular}{|c|c|c|c|c|c|c|c|c|}
\hline Route & $103^{\text {rd }}$ & $77^{\text {th }}$ & $74^{\text {th }}$ & Archer & Kedzie & $\begin{array}{c}\text { Chicago } \\
\text { Ave. }\end{array}$ & $\begin{array}{l}\text { Forest } \\
\text { Glen }\end{array}$ & $\begin{array}{l}\text { North } \\
\text { Park }\end{array}$ \\
\hline \#3 & & 16 & & & & & & \\
\hline$\# 4$ & & 20 & & & & & & \\
\hline$\# 6$ & 11 & 14 & & & & & & \\
\hline$\# 12$ & & & 14 & & & & & \\
\hline$\# 14$ & 13 & & & & & & & \\
\hline$\# 20$ & & & 10 & & & 10 & & \\
\hline \#22 & & & & & & & & $\begin{array}{l}8 \\
6\end{array}$ \\
\hline$\# 29$ & 23 & & 12 & & & & & \\
\hline$\# 36$ & & & & & & & & 11 \\
\hline$\# 56$ & & & & & & & 15 & \\
\hline$\# 60$ & & & & & 25 & & & \\
\hline$\# 62$ & & & & 20 & & & & \\
\hline$\# 65$ & & & & & 10 & 11 & 8 & \\
\hline$\# 66$ & & & & & & 29 & & \\
\hline$\# 124$ & & & & 19 & & & & \\
\hline$\# 126$ & & & 11 & & 7 & & & \\
\hline$\# 146$ & & & & & & & & 12 \\
\hline$\# 147$ & & & & & & & & 8 \\
\hline$\# 151$ & & & & & 8 & & & 13 \\
\hline Total & 47 & 50 & 47 & 39 & 50 & 50 & 23 & 58 \\
\hline
\end{tabular}

Total Buses needed: 364 extras.

Articulated buses are in bold. Foreign garage operations are in italics.

All extra buses will be staged by 1930 hours. 


\section{BUS STAGING LOCATIONS}

Michigan/Roosevelt (Mary Beth Cobleigh-Beal, K-610/Tom Kohler, K-860/Sterling Martin, K-629)

- Michigan (Southbound) between $9^{\text {th }}$ and Roosevelt: \#12 Roosevelt (14 standard)

- Michigan (Northbound) south of Roosevelt: \#6 Jackson Park Express, \#14 Jeffery Express ( 4 standard +4 artics $=8$ total)

- Roosevelt (Eastbound) Wabash to State: \#3 King Drive, \#4 Cottage Grove (6 standard)

- State (SB) Roosevelt to Ninth: \#29 State, \#62 Archer (12 standard)

State/Kinzie (John Meneghini, K-658)

- State (SB) Kinzie to Wacker, Kinzie (EB) Dearborn to State, and Dearborn (NB) Wacker to Kinzie: \#6 Jeffery Express, \#14 Jeffery Express, \#62 Archer (39 standard)

- Wacker (EB) State to Clark: \#146 Inner Drive/Michigan Express, \#151 Sheridan (7 artics)

Dearborn (Dennis Milicevic, K-680/Walter Thomas, K-687)

- Dearborn (NB) Polk to Jackson, Polk (EB) Clark to Dearborn, and Clark (NB) south of Polk: \#22 Clark, \#36 Broadway, \#146 Inner Drive/Michigan Express, \#147 Outer Drive Express, \#151 Sheridan (39 artics +17 standard = 56 total)

Clark (Robert Takagi, K-620/Eugene Thurmond, K-627)

- Clark (SB) Randolph to Van Buren: \#3 King Drive, \#4 Cottage Grove, \#6 Jackson Park Express, \#14 Jeffery Express, \#29 State, \#62 Archer (22 artics + 21 standard = 43 total)

Madison (Fred Schein, K-690/Patricia Thomas-Miller, K-657)

- Madison (WB) Michigan to Dearborn: \#20 Madison and \#56 Milwaukee (35 standard)

- Madison (WB) Clark to Wells: \#60 Blue Island $/ 26^{\text {th }}$ (25 standard)

Adams (Daniel Shurz, K-640/Michael Sanchez, K-667)

- Adams (WB) Michigan to Dearborn: \#126 Jackson (18 standard)

Union Station (Daniel Shurz, K-640)

- Union Station: \#124 Navy Pier (4 standard)

Navy Pier/River North (Robert Bravi, K-660/Antonio McFadden, K-668) New Street: Joe Mitria, K-664B; Jardine: Michael O'Sullivan, K-601

- CTA Terminal: \#65 Grand, \#66 Chicago (10 artics + 12 standard $=22$ total)

- Headhouse: \#29 State: (11 artics)

- Grand (WB) Streeter and LSD: \#124 Navy Pier (6 standard)

- Jardine Water Filtration Plant: \#65 Grand, \#66 Chicago, \#124 Navy Pier (45 standard)

- New (NB) Illinois to North Water: \#29 State (10 artics)

- Chicago (WB) Fairbanks to Inner LSD: \#151 Sheridan (3 artics) 


\section{BOARDING LOCATIONS AND BUS OPERATIONS STAFFING AFTER THE FIREWORKS}

After the fireworks (between approximately 2130 and 2300 hours), customers will board buses at the following locations:

\section{LOCATION $\quad$ MGMT IN CHARGE}

\section{Southbound}

CLARK NEAR SIDE VAN BUREN (Robert Takagi K-620, 907-6819)

\#3 King D. West K-623B, 901-3413; J. Edwards K-623C, 250-5872

\#4 Cottage Grove H. Gauthier K-623A, 398-0285;

J. Perdue K-654C, 250-5941

CLARK NEAR SIDE JACKSON (Robert Takagi K-620, 907-6819)

\#6 Jackson Express $\quad$ E. Watlington K-623C, 250-5947;

D. Ahern K-623B, 901-3431

\#14 Jeffery Express S. Parish K-622A, 807-5216; A. Hollins K-654D, 250-6610

CLARK NEAR SIDE ADAMS (Daniel Shurz K-640, 907-1114)

\#29 State G. Sampract K-642A, 204-1654;

J. McGuire K-643B, 901-2766

\#62 Archer M. Doss K-642B, 290-2895;

B. Longanecker K-643C, 204-3852

Northbound

DEARBORN NEAR SIDE JACKSON (Dennis Milicevic K-690, 907-6791)

\#146 Inner Drive/Michigan Express R. Garcia K-682A, 901-3417; P. Cruz K-683C, 204-3799

\#147 Outer Drive Express $\quad$ K. Seibert K-682B, 250-0989;

C. Chaney K-683B, 250-0818

\#151 Sheridan R. Smith K-682C, 250-6342; M. Ali

DEARBORN NEAR SIDE ADAMS (Dennis Milicevic K-690, 907-6791)

\#22 Clark

J. Lachowicz K-682D, 907-7577; K. Medina, 250-5154

\#36 Broadway

L. Williams K-682E, 204-2051; T. Smith K-683C, 250-6342

\footnotetext{
${ }^{7}$ All phone number area codes are 312 unless otherwise noted. 
Westbound

ADAMS NEAR SIDE CLARK (Daniel Shurz K-640, 907-1114)

\#126 Jackson J. Burns K-642C, 205-1543; B. Kujawa K-643A, 901-2766

MADISON NEAR SIDE STATE (Fred Schein K-690, 907-0811)

\#20 Madison M. Samuel K-694D, 250-5953; A. Rogers K-691, 250-2193

MADISON NEAR SIDE CLARK (Fred Schein K-690, 907-0811)

\#56 Milwaukee E. Jensen K-694A, 272-2195;

R. Davidson K-693, 272-5607

MADISON NEAR SIDE AT WELLS (James Jenkins K-650, 907-2919)

\#60 Blue Island/26th A. Williams K-654E, 250-0695;

C. Ware-Bravi K-651, 901-0016;

N. Figueroa K-653C, $250-3487$

Michigan/Roosevelt

WESTBOUND ROOSEVELT NEAR SIDE MICHIGAN

(Mary Beth Cobleigh-Beal, K-610, 907-1392)

\#12 Roosevelt

H. McFarland K-612E, 901-2813; D. Mitchell

M. Swinford K-613C, 250-5887

\section{EAST BOUND ROOSEVELT FAR SIDE MICHIGAN}

(Mary Beth Cobleigh-Beal, K-610, 907-1392)

\#6 Jackson Park Express J. Musial K-633A, 250-0844; T. Sams

\#14 Jeffery Express H. Aquino K-612C, 272-4042;

L. Ojikutu K-632C, 250-5917

B. Mason K-613A, 204-1305

\section{EASTBOUND ROOSEVELT NEARSIDE INDIANA}

(Mary Beth Cobleigh-Beal, K-610, 907-1392)

\#3 King

C. Rutherford K-612A, 250-0836;

J. Fitzgerald K-612B, 250-9707;

R. Bakievski K-613D, 250-5874

\section{SOUTHBOUND MICHIGAN FARSIDE ROOSEVELT}

(Mary Beth Cobleigh-Beal, K-610, 907-1392)

\#4 Cottage Grove

L. Gregory K-612D, 250-5954; P. Cioffi

J. Ward K-613B, 272-4409

SOUTHBOUND STATE NEARSIDE ROOSEVELT (Tom Kohler K860, 907-2933)
\#29 State
C. Swopes K-632B, 250-0837; Bus Tech Services Mgr.
\#62 Archer
O. Ortiz K-633B, 250-5891; E. Stevens K-633C, 250-5893 


\author{
Navy Pier (Robert Bravi, K-660) \\ HEADHOUSE \\ \#29 State G. Neal K-661, 204-2872; M. Jordan K-664, 250-5956 \\ CTA TERMINAL \\ \#65 Grand J. Murphy K-663A, 272-3187; \\ \#66 Chicago D. Edwards K-663C, 250-5870 \\ D. Hardin K-664C, 250-5961 \\ WESTBOUND GRAND FAR SIDE STREETER \\ \#124 Navy Pier Express $\quad$ M. Tarvid K-663B, 250-1413; M. Ward K-663D, 250-5868 \\ Metra Station Coordination \\ Union Station D. Shurz K-640, 907-1114, (until $2030 \mathrm{hrs)}$ \\ Ogilvie Station G. Sampract K-642A, 204-1654, (until 2000 hrs)
}

\begin{abstract}
Navy Pier Operations
This year, 98 extra buses will serve Navy Pier. Routes include the \#29, \#65, \#66, and \#124. The \#65 and \#66 will stage and board in the CTA terminal operating in a reversed flow from normal terminal operations in order to stage and board more efficiently. Additional \#65 and \#66 buses will feed the terminal from Jardine Water Filtration Plant. The \#29 will stage and board northbound on the boarding island (west half of roadway) in front on Navy Pier, with extras feeding the boarding location from New Street south of Illinois. The \#124 will stage and board westbound on Grand far side Streeter, with extras feeding the boarding location from Jardine Water Filtration Plant.
\end{abstract}

Forty-five buses will be in Jardine Water Filtration Plant. Thirty-nine buses will be staged in the CTA terminal and in front of Navy Pier. Ten will be on New Street. Six will stage westbound on Grand at Streeter. Four of the \#124's will stage at and circulate from Union Station. Of the 39 buses staged at Navy Pier, 11 \#29s will stage in front of the Navy Pier headhouse, 22 \#65s and \#66s will be in the terminal, and 6 \#124s will be on Grand between Streeter and Lake Shore Dr.

\title{
Jardine Security Process
}

As with last year, CTA will follow strict security procedures to utilize Jardine Water Filtration Plant for staging. Bus Heavy Maintenance personnel will work with Jardine security staff and the Chicago Police Department to perform security checks on all operators and buses entering Jardine. Michael O'Sullivan (K-601) will provide the list of bus numbers and operators scheduled to stage in the plant. Pre-checks on Washington at Racine will also be conducted prior to extras entering Jardine. O'Sullivan and his staff will ensure that operators have both their valid driver's license and CTA badge. Operators without both forms of identification will be refused entry to Jardine. 
Operators will not be permitted to leave Jardine once they enter. CTA will provide food and drinks to operators in Jardine. Supervisors will direct buses when inside and while exiting the plant into the Navy Pier terminal.

\section{STATE STREET and MICHIGAN AVENUE CLOSURES and REROUTES}

There will be no bus service on State Street and Michigan Avenue starting at 1800 hours on Saturday, July 3,2004 . This will remain in effect until approximately 2300 hours when the downtown area is clear and most of the outbound loading is complete. CTA will begin rerouting buses on both Michigan and State at $\mathbf{1 8 0 0}$ hours.

Michael Sanchez (K-667) will determine and broadcast the completion of the State and Michigan reroutes and will direct supervisors and managers to put buses over their regular routes.

Buses normally using these streets will be rerouted southbound on Clark and northbound on Dearborn. Affected routes are \#3 King Drive, \#4 Cottage Grove, \#6 Jackson Park Express, \#10 Museum of Science \& Industry, \#14 Jeffery Express, \#29 State, \#36 Broadway, \#62 Archer, \#145 Wilson/ Michigan Express, \#146 Inner Drive/Michigan Express, \#147 Outer Drive Express and \#151 Sheridan.

\#3, \#10, \#145, \#146, \#147 and \#151 buses will be rerouted northbound on Dearborn to Ohio where they will return to Michigan and resume their regular routes. Southbound trips will operate on Ontario and Clark.

\#4 and \#6 buses will be rerouted northbound on Dearborn to Kinzie, then west to Clark to begin their southbound trips. Due to the closure of Michigan these routes will not serve Illinois Center.

\#124 Navy Pier buses will be rerouted in both directions to LaSalle between Madison and Grand. Due to the Michigan closure, \#124 buses will not serve the Randolph Street Metra station. Instead, customers traveling from the station to Navy Pier may board \#29 buses at Dearborn/Lake.

\#20 Madison, \#56 Milwaukee and \#60 Blue Island/26th buses entering downtown from the west will operate east to Wacker before starting new westbound trips on Madison. The $\# 60$ will not be able to serve Harbor Point.

\#126 Jackson buses entering downtown from the west will operate east to Franklin before starting new westbound trips on Adams at Wacker. 


\section{MOBILE REPAIR, TOW TRUCK, REVENUE EQUIPMENT VAN STAGING}

Five mobile repair trucks will be based in the downtown area to assist with any problems associated with the July $3^{\text {rd }} /$ Taste of Chicago extra service. They are Truck 655 at Navy Pier, Truck 615 at State/Kinzie, Truck 685 at Clark/Polk, Truck 639 at Dearborn/Madison, and Truck 675 at Clark/Jackson.

Two trucks will be staged north and south of the Loop. Truck 270 will at LaSalle/Stockton and Truck 210 will be at Wabash $/ 22^{\text {nd }}$.

One revenue equipment van, with Luis Cantu and Bill Moore (K302), will be staged northbound on Canal between Jackson and Van Buren at Union Station.

Four escalator and elevator repair trucks will be staged underneath the Loop elevated structure, under Van Buren, Wells, Lake and Wabash.

\section{BUS OPERATIONS STAFFING}

\section{General Managers/Managers}

Bus Operations general managers will provide staffing coverage for the following corridors:

\begin{tabular}{|c|c|c|}
\hline General Manager & Boarding Areas & Information Specialist Areas \\
\hline $\begin{array}{l}\text { Mary Beth Cobleigh-Beal } \\
\text { Tom Kohler }\end{array}$ & $\begin{array}{l}\text { \#3 - Roosevelt/lndiana } \\
\# 6, \# 14-\text { Roosevelt/Michigan } \\
\# 12-\text { Roosevelt/Michigan } \\
\# 29, \# 62 \text { - State/Roosevelt }\end{array}$ & $\begin{array}{l}\text { Michigan/Roosevelt ( } 9^{\text {th }} \text { to } 14^{\text {th }} \\
\text { and Clark to Columbus) }\end{array}$ \\
\hline Robert Takagi & $\begin{array}{l}\# 6, \# 14 \text { - ClarkNan Buren } \\
\# 3, \# 4 \text { - Clark/Jackson }\end{array}$ & Clark (Wacker to Polk) \\
\hline Patti Hoyle-Heavens & None & $\begin{array}{l}\text { South Loop (Monroe to } 9^{\text {th }} \text { and } \\
\text { Michigan to Dearborm) }\end{array}$ \\
\hline Linda Fuller & None & $\begin{array}{l}\text { North Loop (Lake to Monroe and } \\
\text { Michigan to Dearborn) }\end{array}$ \\
\hline Daniel Shurz & $\begin{array}{l}\text { \#29, \#62 - Clark/Adams } \\
\# 126 \text { - Adams/Clark }\end{array}$ & Union Station, Ogilvie Station \\
\hline Fred Schein & \#20, \#56 - Madison/Clark & Madison (Dearborn to Wacker) \\
\hline Robert Bravi & $\begin{array}{l}\text { \#29 - Navy Pier Headhouse } \\
\# 65 \text {, \#66 - CTA Terminal } \\
\# 124 \text { - Grand/Streeter }\end{array}$ & Navy Pier \\
\hline Dennis Milicevic & $\begin{array}{l}\# 22, \# 36 \text { - Dearborn/Adams } \\
\# 146, \# 147 \text {, \#151 - } \\
\text { Dearborn/Jackson }\end{array}$ & Dearborn (Jackson to Lake) \\
\hline James Jenkins & \#60 - Madison/Wells & \\
\hline
\end{tabular}

Garage General Managers will provide customer information and directions, with assistance from non-operations personnel (Information Specialists) assigned to their coverage area. Michael O'Sullivan will staff Jardine Water Filtration Plant, where buses will be staged. 


\section{Supervisors}

Bus Operations will provide bus service supervisors throughout downtown and at Navy Pier. Supervisors will manage bus service at their assigned locations under the direction of the Bus Service Management Transportation Managers. Supervisors will be located along the major routes: Dearborn, Clark, Roosevelt, New Street, State/Kinzie, Ogilvie and Union Stations, Navy Pier and Jardine, along with other regularly scheduled posts. Michigan Avenue and State Street will be closed to bus traffic $1800-2300$ hours, so supervisors will move from their posts to the reroute and boarding locations to monitor live service and direct staging activities.

\section{Operators}

Training maps and the July $3^{\text {rd }}$ Service Bulletin will be provided to all bus operators providing extra service on foreign routes. In addition, an instruction sheet with routings and correct destination sign codes will be distributed to operators servicing Navy Pier. Operators should be reminded to $\log$ into the farebox and announcement system correctly and to count all rides. Operators will be provided with the Lakefront busway map connecting the Loop to McCormick Place.

Non-Operations Staffing (Information Specialists) Bus Operations has recruited approximately 90 non-operations personnel to assist Bus Operations with customer service. Each non-operations staff member will be assigned to a Garage GM and his/her coverage area. These employees will answer customer questions and direct them to their buses

\section{Public Information}

All information specialists will be provided copies of the Downtown Sightseeing Guide, palm card maps, the CTA system map, and Metra's system map.

The palm cards $\left(4^{n} \times 6^{n}\right.$ maps) include a map of boarding locations for all downtown routes following the fireworks on one side. Bus reroutes after the closure of State Street and Michigan Avenue are listed on the other side. These maps will be distributed to CTA Bus Operations, Rail Operations and Facilities, as well as Chicago Police Department personnel.

See Appendix for these maps.

\section{Other Service}

Bus Operations will transport CPD personnel from the CPD district office at $17^{\text {th }} /$ State at 1600 hours. Extra buses from the State/Kinzie staging area will be used for these trips and will return for staging. Bus Operations will also transport CPD personnel from the CPD Academy at 1300 W. Jackson to the Loop area at approximately 1900 hours. Extra buses from the Clark/Polk staging area will be used for these trips and will return for staging. Walter Thomas (K-687, 9073152 ) will receive the requests and dispatch the buses.

Archer garage will provide four buses to remain available for CDOT or other emergency use. They will be report to New Street, where they will be directed to stage near the busway. Joseph Mitria (K-664B, 907-3442) will be at New Street to dispatch the buses. 


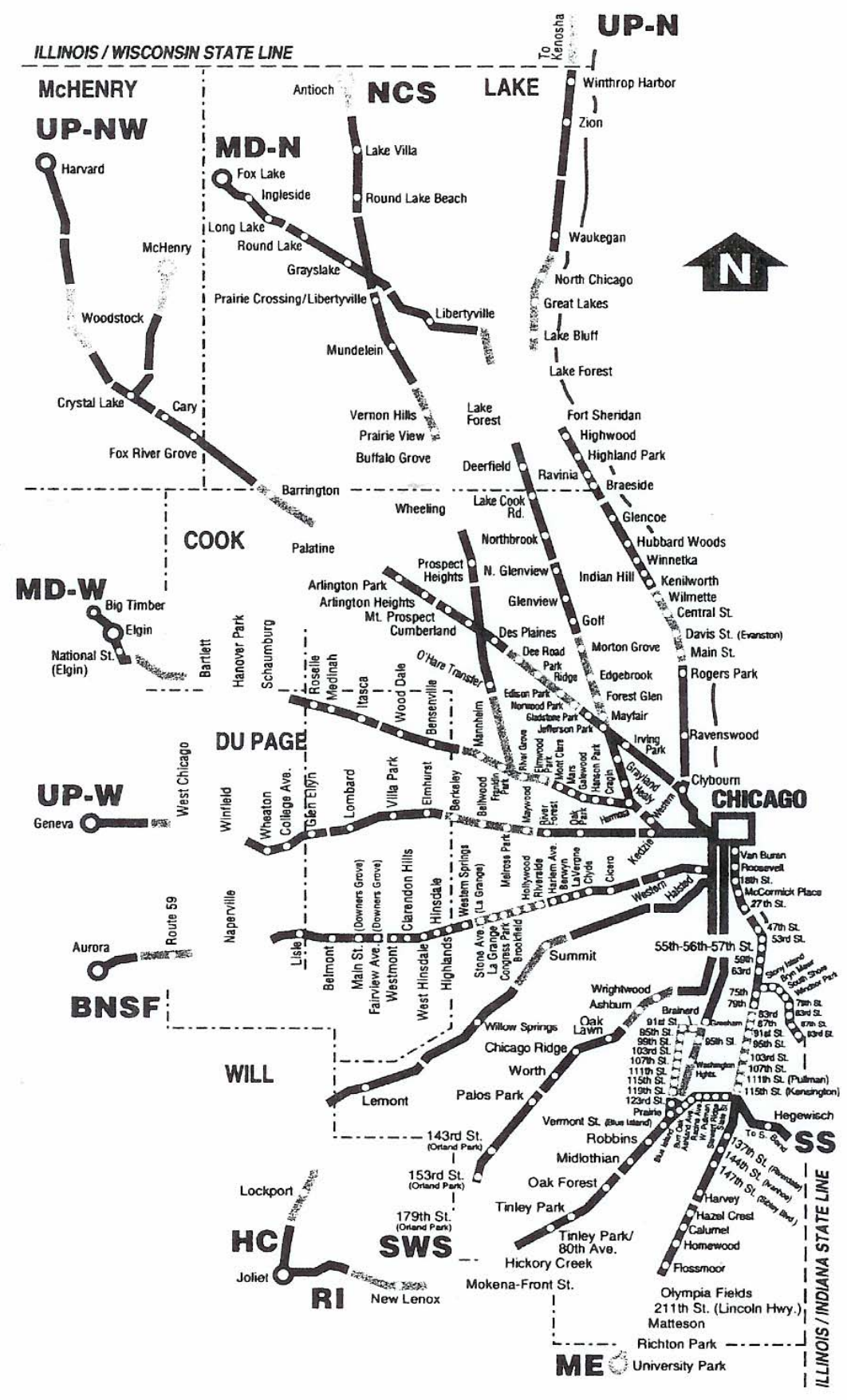

